San Jose State University

SJSU ScholarWorks

Master's Theses

Master's Theses and Graduate Research

1998

\title{
Effect of temperature on shock absorption properties of cushioning materials
}

Kayo Okubo Hatton

San Jose State University

Follow this and additional works at: https://scholarworks.sjsu.edu/etd_theses

\section{Recommended Citation}

Hatton, Kayo Okubo, "Effect of temperature on shock absorption properties of cushioning materials" (1998). Master's Theses. 1632.

DOI: https://doi.org/10.31979/etd.8vqf-zamd

https://scholarworks.sjsu.edu/etd_theses/1632

This Thesis is brought to you for free and open access by the Master's Theses and Graduate Research at SJSU ScholarWorks. It has been accepted for inclusion in Master's Theses by an authorized administrator of SJSU ScholarWorks. For more information, please contact scholarworks@sjsu.edu. 


\section{INFORMATION TO USERS}

This manuscript has been reproduced from the microfilm master. UMI films the text directly from the original or copy submitted. Thus, some thesis and dissertation copies are in typewriter face, while others may be from any type of computer printer.

\section{The quality of this reproduction is dependent upon the quality of the} copy submitted. Broken or indistinct print, colored or poor quality illustrations and photographs, print bleedthrough, substandard margins, and improper alignment can adversely affect reproduction.

In the unlikely event that the author did not send UMI a complete manuscript and there are missing pages, these will be noted. Also, if unauthorized copyright material had to be removed, a note will indicate the deletion.

Oversize materials (e.g., maps, drawings, charts) are reproduced by sectioning the original, beginning at the upper left-hand corner and continuing from left to right in equal sections with small overlaps. Each original is also photographed in one exposure and is included in reduced form at the back of the book.

Photographs included in the original manuscript have been reproduced xerographically in this copy. Higher quality 6" $x$ 9" black and white photographic prints are available for any photographs or illustrations appearing in this copy for an additional charge. Contact UMI directly to order.

\section{UMI}

A Bell \& Howell Information Company 300 North Zeeb Road, Ann Arbor MI 48106-1346 USA

$313 / 761-4700 \quad 800 / 521-0600$ 



\title{
EFFECT OF TEMPERATURE ON SHOCK ABSORPTION PROPERTIES OF CUSHIONING MATERIALS
}

\author{
A Thesis \\ Presented to \\ The Faculty of the Department of Nutrition and Food Science \\ San Jose State University \\ In Partial Fulfillment \\ of the Requirements for the Degree \\ Master of Science
}

by

Kayo Okubo Hatton

May, 1998 
OMI Number: 1389643

Copyright 1998 by Hatton, Rayo Okubo

All rights reserved.

UMI Microform 1389643

Copyright 1998, by UMI Company. All rights reserved.

This microform edition is protected against unauthorized copying under Title 17, United States Code.

\section{UMI \\ 300 North Zeeb Road \\ Ann Arbor, MI 48103}


(C) 1998

Kayo Okubo Hatton

ALL RIGHTS RESERVED 
APPROVED FOR THE DEPARTMENT

OF NUTRITION AND FOOD SCIENCE

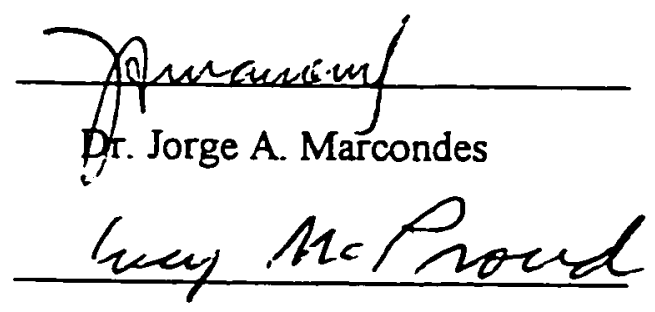

Dr. Lucy McProud

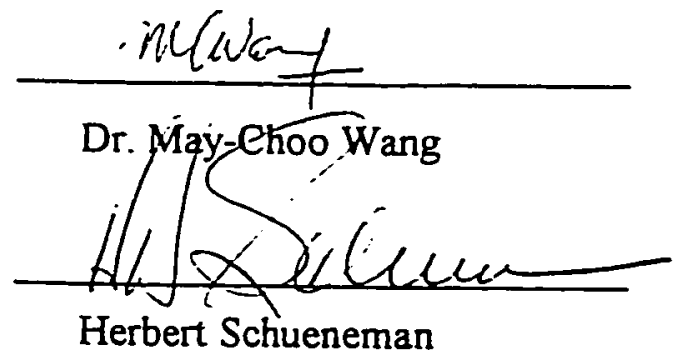

APPROVED FOR THE UNIVERSITY

terence 9.ptanfore 


\section{ABSTRACT \\ EFFECT OF TEMPERATURE ON SHOCK ABSORPTION PROPERTIES OF CUSHIONING MATERIAĹS}

by Kayo Okubo Hatton

Cushioning materials are used in packaging as one of the ways to provide protection. Cushion curves for commonly used cushioning blocks are widely available; however, the effect of temperature on shock absorption properties has not been well studied. The objective of this study was to investigate the effect of temperature on shock absorption properties of three of the most commonly used cushioning materials: expanded polyurethane (EPU) foam, expanded polyethylene (EPE) foam, and expanded polystyrene (EPS) foam. The effect of temperature was investigated by testing cushioning blocks that were conditioned at four different temperatures $\left(-17^{\circ} \mathrm{C}, 3^{\circ} \mathrm{C}\right.$, $23^{\circ} \mathrm{C}$, and $43^{\circ} \mathrm{C}$ ). Results indicated that the shock absorption properties of EPU and EPE foams did vary with temperature. No notable temperature effect was noted for EPS foams. Analysis was performed on the EPU and EPE foams to derive formulae for determining the static loading and minimum deceleration for a given temperature. 


\section{ACKNOWLEDGMENTS}

I would like to thank my graduate advisor, Dr. Jorge A. Marcondes, for his insightful technical guidance throughout my course of studies at San Jose State University. His knowledge, practical advice, and encouragement made it possible for me to complete this research. I would also like to thank Dr. Lucy McProud for her precise guidance and assistance in this research. I would like to express thanks to Dr. May-Choo Wang for her valuable support and numerous suggestions, especially during the manuscript process, and Herbert Schueneman at Westpak, Inc. for his pragmatic suggestions and technical direction.

Finally, I would like to thank my husband, Wayne Hatton, for his continuous support, understanding, and encouragement throughout my studies at San Jose State University. 


\section{PREFACE}

The following is a publication style thesis. The second chapter is written in journal format and will be submitted to Packaging Technology and Science. Chapter 1 and 3 are written according to guidelines outlined in the Publication Mamual of the American Psychological Association, 4th edition, 1994. 


\section{Table of Contents}

\section{Page}

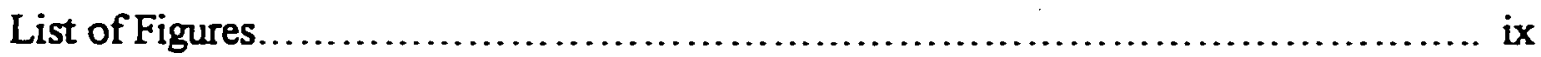

List of Acronyms and Abbreviations ..................................................

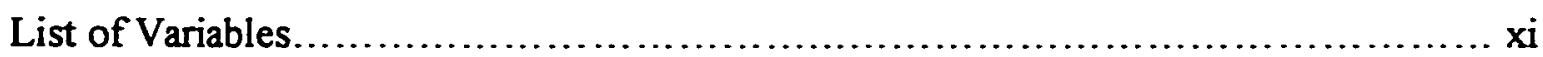

\section{CHAPTER}

1 INTRODUCTION AND REVIEW OF LITERATURE

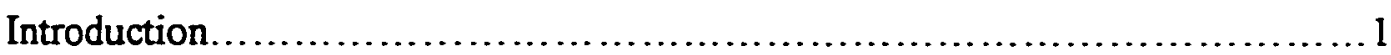

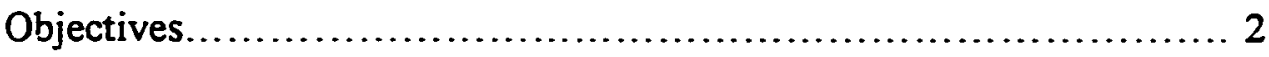

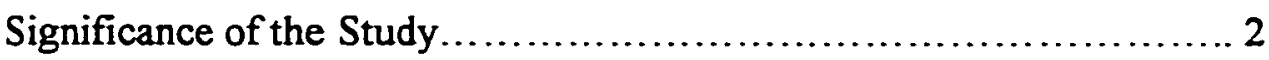

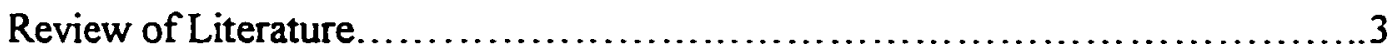

Elastic Cushioning Materials........................................ 4

Open-cell Foams............................................ 5

Closed-cell Foams............................................ 6

Non-elastic Cushioning Materials..................................

Solid Foams................................................. 7

Loose Fill Cushioning Materials............................. 10

Molded Pulp Cushioning Materials............................ 12

Temperature and Cushioning Materials............................... 13

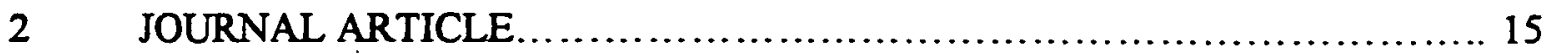

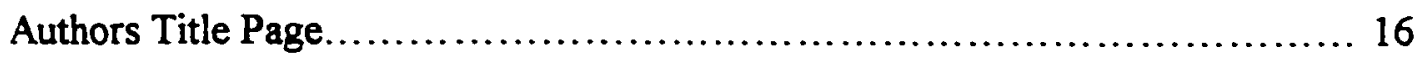




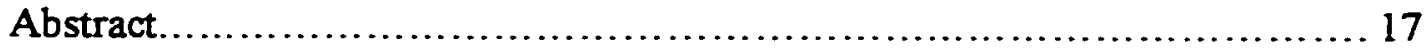

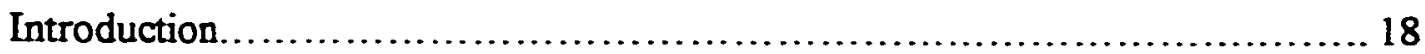

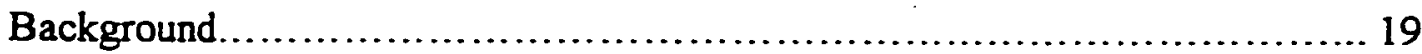

Experimental Design.................................................... 22

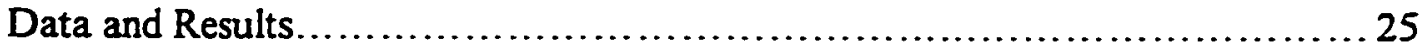

Cushion Curves.................................................... 25

Formulae of Best-fit Regression Lines............................ 26

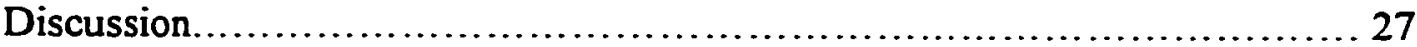

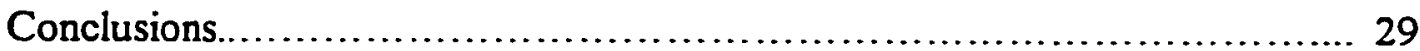

Acknowledgement.................................................... 30

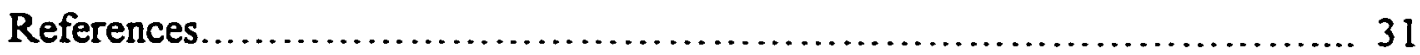

3 SUMMARY AND RECOMMENDATIONS

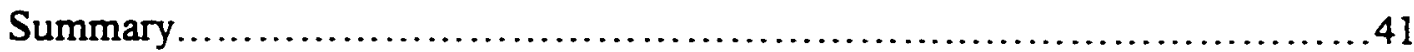

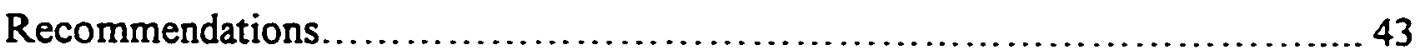

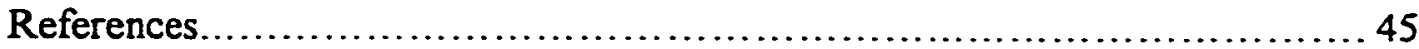

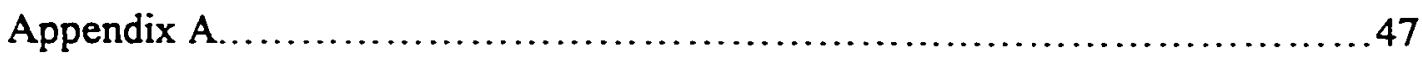

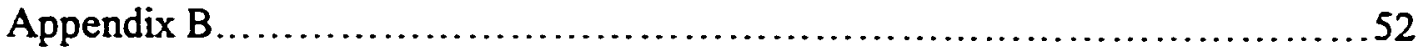




\section{List of Figures}

Figure

Page

1. Cushion curves for EPU foam at various temperatures (30" drop height,

$1^{\text {sf }}$ impact)

2. Cushion curves for EPS foam at various temperatures (30" drop height,

$1^{\text {st }}$ impact)

3. Cushion curves for EPE foam at various temperatures (30" drop height, $1^{x}$ impact)

4. Relationship between temperature and deceleration of EPE foam

5. Relationship between temperature and static loading of EPE foam

6. Relationship between temperature and deceleration of EPU foam

7. Relationship between temperature and static loading of EPU foam

8. Relationship of minimum deceleration, static loading, and temperature (30" drop height, $1^{\text {s }}$ impact) 


\title{
List of Acronyms and Abbreviations
}

\author{
ASTM = American Society for Testing and Materials \\ $\mathrm{EPE}=$ expanded polyethylene \\ EPS = expanded polystyrene \\ EPU = expanded polyurethane \\ ISTA = International Safe Transit Association
}




\section{List of Variables}

$$
\begin{array}{ll}
\mathrm{D} & =\text { deceleration }(\mathrm{g}) \\
\mathrm{g} & =\text { acceleration of gravity }\left(386.4 \mathrm{in} / \mathrm{s}^{2}\right) \\
\mathrm{h} & =\text { drop height (inches) } \\
\mathrm{ILD} & =\text { indent load deflection } \\
\mathrm{pcf} & =\text { pounds per cubic foot } \\
\mathrm{R} & =\text { correlation coefficient } \\
\mathrm{S} & =\text { static loading (psi) } \\
\mathrm{T} & =\text { temperature }\left({ }^{\circ} \mathrm{C}\right) \\
\mathrm{V} & =\text { impact velocity }(\mathrm{in} / \mathrm{s})
\end{array}
$$




\section{CHAPTER 1}

\section{INTRODUCTION AND REVIEW OF LITERATURE}

Introduction

One of the goals of packaging engineering is to ensure that a product moves from the point of production to the point of sale, without unacceptable loss or damage (Bandenburg, 1993). The packaging engineer's deliverables must also be accomplished in an economical and practical manner. Most products need protective packaging because they are designed only to survive their intended use and not the harsh demands associated with the distribution environment (Marcondes, 1997). Of the various types of hazards that exist in the distribution environment, the following are the most common: impacts, puncturing and deformation due to manual handling, vibration due to vehicle motion, compression due to stacking, low atmospheric pressure due to high altitude, and variation in relative humidity $(\mathrm{RH})$ and temperature (Soroka, 1995). Since most products cannot sustain the stresses caused by the hazards described above, protective packaging is necessary to mitigate such effects on products during distribution.

One of the ways to provide protection during distribution is to use cushioning materials. Cushioning materials are employed mainly to protect products from impact and vibration. It is the packaging engineer's responsibility to find a suitable material configuration that will successfully and dependably attenuate any forces encountered during distribution to a level that will not cause unacceptable damage to the product. Although technically feasible, it may not be economically viable to eliminate all possible hazards in actual practice since the balance of the cost of protection (packaging cost) 
versus the cost of damage weighs heavily on the product's ultimate economic viability (Marcondes, 1997).

There is a wide selection of cushioning materials available on the market today, ranging from traditional molded plastic to the newer starch-based popcorn packaging materials (Hanlon, 1992). Each cushioning material has different mechanical properties and these properties are likely influenced by temperature. However, the actual effects of temperature on the mechanical properties of some materials have not been thoroughly studied. Among various types of cushioning materials, cushioning blocks are broadly used in today's industries. This research, in keeping with industry trends, focused exclusively on cushioning blocks. Furthermore, this study was restricted to only the shock absorption properties of these materials. These properties are the most commonly referenced for cushion design of protective packaging.

\section{$\underline{\text { Objectives }}$}

The objective of this study was to determine if temperature affects the shock absorption properties of three of the most commonly used protective packaging foams: expanded polyurethane (EPU) foam, expanded polyethylene (EPE) foam, and expanded polystyrene (EPS) foam. When there were temperature effects, efforts were made to quantify the effect.

\section{Significance of the Study}

Today, protective packaging is designed based on available cushion curves constructed solely at ambient temperature and ambient $\mathrm{RH}$, regardless of the type of distribution environment a package may experience. Currently, temperature is not a 
factor that is considered when designing protective packaging. However, any change in the shock absorption properties of the cushioning material due to temperature can lead to insufficient product protection. Inadequate protection resulting in product damage can inflict serious corporate economic loses, not only in the loss of marketable products, but also the replacement costs of these products. Consequently, the study of temperature effect on shock absorption properties of cushioning materials is of considerable importance when designing proper protective packages.

Review of Literature

The typical elements of information necessary to design protective packaging are related to shock, vibration, and compression (Marcondes, 1997). These elements of information need to be obtained from three areas: distribution environment, product, and packaging material.

For shock, the expected drop height due to manual handling in the distribution environment and product shock fragility are the principal package design parameters. To quantify the shock absorption characteristics of cushioning foams, cushion curves are used (Marcondes, 1997). Cushion curves are obtained by testing the cushioning materials for the parameters of drop height and material thickness. These curves describe the transmitted deceleration in units of $\mathrm{g}\left(1 \mathrm{~g}=\right.$ acceleration of gravity $\left.=386.4 \mathrm{in} / \mathrm{s}^{2}\right)$ versus the static loading that a material can withstand (Harris, 1988). The maximum transmitted deceleration is the maximum intensity of a shock transmitted through a cushion to the test object when an item is dropped flat on top of the cushion from a specified height. Curves are usually constructed in accordance with American Society for Testing and Materials 
(ASTM) standard test method D-1596, "Standard Test Method for Dynamic Shock Cushioning Characteristics of Package Material" (ASTM, 1994). This measures the maximum acceleration at various static loadings (the ratio, mass/contact area, in psi). Each static loading is usually obtained by changing the weight of the load while maintaining a constant contact area.

In general, cushioning materials can be categorized into two broad groups: elastic (flexible or resilient) and non-elastic (crushable) (Harris, 1988). Elastic cushioning materials are defined as materials that sustain no more than an arbitrarily selected amount of permanent deformation when deflected due to an external impact (Harris, 1988). Materials that are crushable and sustain more than an arbitrarily selected amount of permanent deformation when deflected during an impact are classified as a non-elastic cushioning material (Harris, 1988).

\section{Elastic Cushioning Materials}

Many of the molded plastic foams fall into this category. When looking closely at these materials, it can be observed that two different cell structures exist: open-cell foam and closed-cell foam. An open-cell foam consists of a network of interconnected cells, where air is capable of freely flowing in-between the cells and even out of the cushioning material itself (Burgess, 1993). Open-cell foams absorb energy by transferring displaced air through the cells. Expanded polyurethane (EPU) foam is an example of an open-cell type foam. In comparison, a closed-cell foam consists of individual bubbles of air trapped within a thin unbroken membrane of plastic. These trapped bubbles of air absorb energy by compressing the air within the cells (Burgess, 1993). Expanded polystyrene 
(EPS) foam and expanded polyethylene (EPE) foam are common closed-cell cushioning materials. EPS foam, however, differs from EPE foam in that it has non-elastic properties while EPE foam has elastic properties (Burgess, 1993).

\section{Open-cell Foams}

Expanded polyurethane (EPU) foam is the most commonly used cushioning choice of open-cell foams. It is usually used for lightweight products as well as cushioning for furniture and medical applications.

Cushion curves for EPU foams are widely available. Nevertheless, the effects of the shape of the cushion test block on the curve were not well understood and had not been thoroughly investigated until Sims and Bennett decided to ascertain a more detailed relationship (Sims \& Bennett, 1995). Sims and Bennett studied the effects that different shaped open-cell polyester PU foam had on the cushion curve and deformation behavior of the material (Sims \& Bennett, 1995). They also examined whether or not identical cushion curves could be obtained using different test methods for the static loadings by using two inch thick PU foam samples at a 7.9 inch drop height (Sims \& Bennett, 1995). In the traditional test method, the mass is varied with a constant contact area. Using an alternative method, the contact area was varied while the mass was held constant to obtain the same static loadings. In their study, five samples were dropped 20 times each per static loading, in order to construct the cushion curves. Only the results of the third through the twentieth drop were used to calculate the average of the maximum acceleration value obtained in each drop. The results indicated that there was a substantial difference between the new test condition versus the traditional method. The 
maximum acceleration for a certain static loading that was obtained from a traditional cushion curve was lower than the maximum acceleration obtained from a cushion curve using the altemative method. This was especially true at higher static loading conditions. This phenomenon was thought to be due to the effects of changing the open surface area to volume ratios. This change affected the air flow and balance of compression (Sims \& Bennett, 1995).

\section{Closed-cell Foams}

The foams with closed-cell structures are usually stiffer and more durable than their open-cell foam counterparts (Burgess, 1993). Expanded polyethylene (EPE) foam and expanded polypropylene (EPP) foam are well known as closed-cell foams with elastic properties. Since closed-cell foams absorb impact energy by compressing air trapped inside, the original cell structure may be transformed into a new shape after each subsequent impact (Burgess, 1993). Multiple drops may have a pronounced effect on closed-cell foams whereby the cushion curves of multiple drops may dramatically differ from the common cushion curves (which are based on the average of second through the fifth drop). Totten, Burgess, and Singh (1990) investigated the effects of multiple drops on closed-cell foams by using four different commercially available closed-cell foams: Ethafoam 220, (a Dow Chemical EPE product), and three ARCO Chemical products: ARPRO, ARCEL, and ARPAK, which are expanded polypropylene foam (EPP), moldable polyethylene (PE) copolymer, and expanded PE foam respectively. Testing was conducted according to ASTM D-1596. The cushion curves for the first, fifth, and fifteenth drop were constructed for drop heights of 24, 30 and 36 inches using four 
different static loading conditions and two samples for each condition. As expected, the results indicated that as the number of impacts increased, the transmitted deceleration also increased. The mean percentage increase in transmitted shock between the fifth and fifteenth drops was 9.6 percent for ARPAK (EPE), 11.3 percent for ARPRO (EPP), and 17.3 percent for ARCEL (moldable PE). Therefore, the cushion curves based on the average of the second to fifth drops (common method) may not be adequate for describing the cushion behavior under conditions where multiple impacts are expected during distribution (Totten et al., 1990). Any relation between their results and temperature was not noted.

\section{Non-elastic Cushioning Materials}

EPS foam is one of the most common non-elastic materials, and has a closed-cell foam structure. EPS foam is available in either solid foam or loose fill foam, manufactured from both virgin material and recycled material. The loose fill packaging material has received more attention due to recent environmental concerns. As a result, manufacturers are now actively developing many varieties of this type of material for the market (Singh, Chonhenchob, \& Burgess, 1994).

\section{Solid Foams}

Studies have been conducted on solid EPS foams, a closed-cell material, for both natural and recycled foams. One such study is Lye, Teo and Lew's (1995) experiment that studied the general shock absorption properties of EPS foam by employing solid block EPS foam samples. They examined the effects of impact surfaces and the effects of the cushioning material configuration in addition to the effects of material density on 
transmitted deceleration. The results showed that as the impact surface's rigidity increased, so did the shock level transmitted to the product. The test results also indicated that positioning the cushioning material's supporting configuration closer to the product's center of gravity lessened the amount of shock transmitted to the product. Furthermore, denser materials transmitted lesser amounts of shock. Materials like EPS foam, which are very dense, therefore seem to be better choices for heavier products. The results of this study demonstrated that the shock absorption characteristics of EPS foam are a function of impact surfaces, cushion configurations, and cushion density (Singh et al., 1994). There was no indication regarding temperature conditions during this testing.

EPS is a thermoplastic that will soften at high temperatures and pressures. Although at first glance it may not seem to be highly desirable, this property can be an advantage since it allows the material to be recycled up to a certain limit (Soroka, 1995).

Pirie, Hornberger, Mohareb, and Hight (1994) studied the shock absorption properties of cushioning materials that contained several different percentages of recycled EPS foam in order to determine the feasibility of increasing its recycled presence in packaging applications. Virgin beads of solid EPS were blended with 100 percent recycled beads to the appropriate ratio to obtain different percentage levels of recycled content $(25,50,75$ and $100 \%)$. The same study extended the investigation into the static compression properties of the same EPS foam samples (Mohareb, Homberger, Pirie, \& Hight, 1994). All subject samples were cut into 8" $\times 8$ " $\times 2$ " dimensions and conditioned at $65 \% \mathrm{RH}$ and $23.5^{\circ} \mathrm{C}$ for a period of at least 16 hours prior to testing. The ASTM D- 
1596 method was selected for constructing the cushion curves. Three parameters, density, compressive strength and creep characterization, were used to study the material's static compression properties (Pirie et al., 1994; Mohareb et al., 1994).

According to the generated cushion curves, the cushioning performances of the recycled EPS foam and the natural EPS foam were very similar to each other below a static loading of $1.2 \mathrm{psi}$. However, at higher static loading conditions, the maximum acceleration of the natural and the $25 \%$ recycled content blend materials transmitted the least deceleration among the various blended samples. For instance, at $10 \mathrm{psi}$, the $100 \%$ recycled content foam transmitted as much as $20 \%$ more deceleration than the natural EPS foam (Pirie et al., 1994).

Although the recycled material is readily recognized as a lower grade material, these results have encouraged the industry to vigorously use more recycled EPS blended solid foams in protective packaging applications. This trend has also gained momentum for loose type fills as well (Mohareb et al., 1994).

The studies by Sims and Bennett (1995), Totten et al. (1990), and Pirie et al. (1994) indicated that their experiments were conducted under equal ambient temperature $\left(23^{\circ} \mathrm{C}\right.$ to $\left.25^{\circ} \mathrm{C}\right)$ and equal ambient $\mathrm{RH}(50 \%$ to $65 \%)$. Equal test conditions are very important for examining a material's true cushioning properties without introducing any additional variables. Nevertheless, there was no study, in the articles reviewed, which examined the relationship of the shock absorption properties versus temperature.

Since samples were not randomly selected in all of the articles reviewed, the experimental design is assumed to be quasi-experimental. This leads to the possibility of 
biased sample selection and thus a limitation in all studies reviewed. Moreover, ASTM D-1596 standard method does not state desirable sample sizes for cushion curve construction. Many studies that referred to this testing method therefore did not state the sample size or used very small sample sizes. Furthermore, since all the samples of cushioning materials used in these studies were synthetic, which are more homogeneous than natural materials, the variability of these samples could be assumed to be very small. Loose Fill Cushioning Materials

As with other cushioning materials, many different types of loose fill cushioning materials are also available on the market today. However, since Municipal Solid Waste (MSW) is posing a serious problem to our ecosystem and the fact that one third of all MSW is generated from packaging, today's more environmentally responsible consumers are putting a higher priority on "green" packaging (Selke, 1990). Approximately $65 \%$ of all loose fill cushioning materials are used in molded or fabricated form by mail order companies in the United States that ship various products in an array of sizes and weights (Singh et al., 1994). Among various loose fill cushioning materials, EPS loose fill occupies the highest percentage of market share and owes its popularity to the fact that it is light in weight, low in cost and more convenient to dispose (Singh et al., 1994). The remaining market segments are shared between paper-based and starch-based materials. These two materials are considered environmentally friendly and are expected to capture more and more market share in the future (Singh et al., 1994).

The cushioning performance of various loose fill materials, including $100 \%$ recycled EPS, popcorn, corrugated trim, wood shavings and starch-based and paper- 
based peanuts, were studied in terms of their protective level as well as the amount of material required by weight. Since there was no ASTM standard test method to measure the transmitted shock leveis for loose fill materials, ASTM D-4168 for foam-in-place cushioning was used as a proxy (ASTM, 1994). The comparison of various loose fill cushions was presented in terms of an "environmental cushion curve" where the transmitted shock level was displayed as a function of the ratio of cushion weight to product weight. For each sample, a corrugated box was filled with the loose fill material to a depth of three inches. The maximum acceleration was measured by dropping a cubical test block weight, in a free fall, from three different heights: 24,30 and 36 inches into the corrugated box (Singh et al., 1994).

The resulting shock absorption performance of the seven loose fill materials clearly indicated that materials such as popcorn and wood shavings showed very poor material utilization. Poor material utilization means that these cushioning materials required larger amounts of material, both by weight and volume, in order to achieve a similar level of protection as the other loose fill cushioning materials. The $100 \%$ recycled EPS samples displayed the best performance in terms of percent weight utilization due to their low density and good shock attenuation properties. Similarly, both the starch-based loose fill and the paper-based loose fill also showed good performance in terms of their efficient use by volume for a given level of protection. Despite how much material was used, some loose fill materials were incapable of attenuating the shock to a prescribed level (Singh et al., 1994). 


\section{Molded Pulp Cushioning Materials}

Molded pulp is a three-dimensional product that is manufactured from aqueous slurry of cellulosic fibers. This slurry can include virgin wood pulp and recycled pulp (Eagleton \& Marcondes, 1994). Egg cartons, for instance, are made of molded pulps.

A study was conducted to compare the cushion curves of molded pulp materials to the cushion curves for EPS foams. The shock absorption properties of the molded pulp result from a number of physical "dimples" molded into the pulp sheet which are crushed when absorbing the energy imparted from an external shock (Eagleton \& Marcondes, 1994).

The molded pulp test samples had good cushioning characteristics for low static loadings (below $0.73 \mathrm{psi}$ ), low drop heights (below 11.8 inches), and single impacts. However, they showed poor performance at higher static loadings, higher drop heights, and when multiple impacts occurred. Under these conditions, which are more common in an actual distribution environment, the EPS samples exhibited very good shock absorption. Interlocking dimples, which consisted of two samples on top of each other, improved the molded pulp's shock absorption properties and achieved cushioning properties similar to those as the EPS samples at lower static loadings, lower drop heights, but multiple impacts. It was concluded that molded pulp cushioning materials had the potential to replace EPS foam in limited situations where conditions were not as severe, such as lower static loading, lower drop height and lower number of impacts (Eagleton \& Marcondes, 1994). 
Marcondes (1998) further studied shock and vibration properties of molded pulp by making use of molded pulps of varying rib dimensions. The cushion curves were constructed by plotting transmitted deceleration versus perimeter loading (lb./in). This value represents the ratio between product weight and the perimeter of the contact rib area (Marcondes, 1998). Since these curves depicted curves very similar to the cushion curves of cushioning materials it was determined that they could be employed in the same manner (Marcondes, 1998). The results revealed that the higher ribs displayed better protection performance for repeated impacts, however, destruction of molded pulps occur after only a few drops, especially for shallow molded pulps (Marcondes, 1998). The shock transmission by combined ribs was similar to the single rib shock transmission, as long as the perimeter loading was held constant (Marcondes, 1998).

\section{Temperature and Cushioning Materials}

In a distribution environment, product-package systems can experience many detrimental hazards. One of the hazards is temperature. Temperature can affect not only the product, but the packaging as well. Since the three cushioning materials chosen for this study are all made from plastics, when they are exposed to higher or lower temperatures they will soften or harden respectively. Consequently, an assumption can be made that the shock absorption properties also change and that the changes will be different depending on the structure of the particular cushioning material.

Most of the studies that were reviewed focused on the shock absorption properties of materials, without an investigation of the effects of temperature on their performance. The effect of temperature on compression properties of cushioning materials is more 
commonly recognized among packaging engineers, in the form of stress-strain curves. As temperature increases, the strain (\%) increases at the same stress loading (Dow Chemical, 1987).

The cushion curves of EPE foam at different temperatures $\left(-40^{\circ} \mathrm{C},-17^{\circ} \mathrm{C}\right.$, and $71^{\circ} \mathrm{C}$ ) for the drop height of 12,24 and 36 inches are published in Dow Chemical Product and Design Data handbook (Dow Chemical, 1987) and indicate a significant difference in the shape of the cushion curves. However, besides the cushion curves for these three discrete values, no further analyses were ever reported for applying the data for a continuum of temperatures. 
CHAPTER 2

JOURNAL ARTICLE 
Authors Title Page

EFFECT OF TEMPERATURE ON SHOCK ABSORPTION PROPERTIES

OF CUSHIONING MATERIALS

Kayo O. Hatton, Jorge A. Marcondes*, Lucy McProud, May-Choo Wang, and Herbert Schueneman ${ }^{(1)}$

Department of Nutrition and Food Science

San Jose State University

One Washington Square, San Jose, CA 95192

and ${ }^{(1)}$ Westpak, Inc.

134 Martinvale Lane, San Jose CA 95119

* Address questions and comments to: Dr. Jorge A. Marcondes,

Department of Nutrition and Food Science, San Jose State University,

One Washington Square, San Jose, CA 95192-0058, 408-924-3210 


\section{ABSTRACT}

Cushioning materials are used in packaging as one of the ways to address the protective needs, mainly to protect products from shock and vibration. Cushion curves for commonly used cushioning blocks are widely available; however, the effects of temperature on their shock absorption properties have not been well studied. Changes in the stiffness of cushioning blocks that are made from plastic polymers have been observed in the presence of changes in temperature. This suggests that there is a strong likelihood that temperature directly affects the shock absorption properties of plastic polymer cushioning materials. This study investigated the effect of temperature on the shock absorption properties of three commonly used cushioning blocks, expanded polyurethane (EPU) foam, expanded polyethylene (EPE) foam, and expanded polystyrene (EPS) foam. The effect of temperature was investigated by testing cushioning blocks that were conditioned at four different discrete temperatures $\left(-17^{\circ} \mathrm{C}\right.$, $3^{\circ} \mathrm{C}, 23^{\circ} \mathrm{C}$, and $43^{\circ} \mathrm{C}$ ). The results indicated that there was a notable temperature effect on the shock absorption properties of EPU and EPE foams, despite only a minimal effect on the EPS foam. Analysis was performed on the EPU and EPE foams to obtain formulae for determining minimum deceleration and static loading for a given temperature.

Keywords: cushioning material, temperature effects, cushion curves

Running headline: Temperature effects on cushioning materials 


\section{INTRODUCTION}

One of the functions of packaging is to protect products from possible hazards encountered during distribution without unacceptable loss or damage. Of the various types of hazards that exist in a distribution system, the following are the most common: impacts, puncturing and deformation due to manual handling, vibration due to vehicle motion, compression due to stacking, low atmospheric pressure due to high altitude, and humidity and temperature variation [1]. Since most products cannot sustain the stresses attributable to the hazards above, protective packaging is used to mitigate their effects on products during distribution. It is the packaging engineer's responsibility to find a suitable material configuration that will successfully and dependably attenuate any impacts encountered during distribution to a level that will not cause unacceptable damage to the product.

Cushion curves are the traditional method for quantifying shock absorption characteristics of cushioning foams. These curves are obtained for different drop heights and material thickness and describe the transmitted deceleration in units of $\mathrm{g}(\mathrm{lg}=$ acceleration of gravity $=386.4 \mathrm{in} / \mathrm{s}^{2}$ ) versus the static loading [2]. The transmitted deceleration is the maximum intensity of a shock transmitted to a test object when an item is freely dropped flat from a specified height over the cushion [3]. The cushion curves of various commercial cushioning materials are widely available for the first impact and the average of the second to fifth impacts, in accordance with ASTM D-1596, 
"Standard Test Method for Dynamic Shock Cushioning Characteristics of Package Material" [3].

The effect of temperature on the shock absorption properties of cushioning materials has not been well studied, although, it has been previously postulated that the stiffness of these cushioning blocks is dependent on temperature [4]. ASTM D-1596 suggests that cushion test conditions should be at a standard conditioning atmosphere of $23 \pm 2{ }^{\circ} \mathrm{C}$ and $50 \pm 2 \%$ relative humidity, in the absence of other requirements [3]. Most of the published data follows this suggested standard condition and the effect of temperature is largely ignored. Ignored even though a change in the shock absorption properties at various temperatures could lead to product damage due to inadequate protection.

The objective of this study was to investigate the effect of temperature on the shock absorption properties of three of the industry's most commonly used cushioning materials: expanded polyurethane (EPU) foam, expanded polystyrene (EPS) foam, and expanded polyethylene (EPE) foam. Additional tests were also undertaken to quantify any effect of temperature on the shock absorption properties. ASTM D-1596 was referenced in constructing the cushion curves used in this study [3].

\section{BACKGROUND}

Packaging cushioning materials can be categorized into two general groups: elastic (flexible or resilient) or non-elastic (crushable) [2]. Elastic cushioning materials are defined as materials that sustain no more than an arbitrarily selected amount of 
permanent deformation when deflected due to an external impact [2]. Many of the molded solid plastic foams fall into this category. When looking closely at these materials, it can be observed that two different cell structures exist: open-cell foam and closed-cell foam. An open-cell foam consists of a network of interconnected cells where air is capable of flowing freely between the cells, and even out of the cushioning material itself [5]. Open-cell foams absorb energy by transferring displaced air through the cells. EPU is a classical example of an open-cell type foam. In comparison, a closed-cell foam consists of individual bubbles of air trapped within a thin unbroken membrane of plastic. These trapped bubbles of air absorb energy by compressing the air within the cells [5]. Both EPS and EPE foams are common closed-cell cushioning materials. However, EPS foam differs from EPE foam in that it has non-elastic properties while EPE foam has elastic properties [5].

EPU foam is the most common commercially used cushioning choice of all opencell foams. It is typically used for lightweight products, as well as cushioning for furniture and medical applications. Cushion curves for EPU foam are available, however, the effects of temperature have not been well studied.

Closed-cell foam structures are usually stiffer and more durable than their opencell foam counterparts [5]. EPE foam is well known as a closed-cell foam with elastic properties. Since closed-cell foams absorb impacted energy by compressing air trapped inside of individual cells, the original cell structure may be transformed into a new shape after each subsequent drop test [5]. Multiple drops therefore may have a pronounced effect on closed-cell foams whereby the cushion curves of multiple drops may 
dramatically differ from the common cushion curves (which are based on the average of the second through the fifth drop). A study investigated the effects of multiple drops on closed-cell foams by using four different commercially available closed-cell foams including EPE (Ethafoam 220, a Dow Chemical EPE product) foam [6]. However, the relationship between the results and temperature was not noted. The cushion curves for Ethafoam $220\left(\mathrm{EPE}\right.$ foam) at three different temperatures, $-40^{\circ} \mathrm{C}\left(-40^{\circ} \mathrm{F}\right),-18^{\circ} \mathrm{C}\left(0^{\circ} \mathrm{F}\right)$, and $71^{\circ} \mathrm{C}\left(160^{\circ} \mathrm{F}\right)$, have been published by Dow Chemical [4]. The data indicated a trend with higher temperatures corresponding to higher transmitted deceleration and lower static loading; however, no further analysis were ever reported for applying the data across a continuum of temperatures [4].

Materials that are crushable and sustain more than an arbitrarily selected amount of permanent deformation when deflected during an impact are classified as non-elastic [2]. EPS foam, a material with a closed-cell foam structure, is the most common nonelastic material and is available in both solid foam and loose fill foam. EPS foam is manufactured from both virgin material and recycled material. A study was conducted to examine the effects of impact surfaces, the effects of the cushioning material configuration, as well as the effects of material density on shock absorption [7]. The results of this study demonstrated that the shock absorption characteristics of EPS are a function of impact surfaces, cushion configurations, and cushion density [7]. Unfortunately, there was never any mention of temperature conditions during this testing. 


\section{EXPERIMENTAL DESIGN}

The three different solid cushioning materials used in this study were DOW Chemical's expanded polyethylene (EPE: ETHAFOAM 220, 2.2 pcf) foam, Western Insulfoam's expanded polystyrene (EPS, $1.0 \mathrm{pcf}$ ) foam, and Crain Industry's expanded polyurethane (EPU, $1.8 \mathrm{pcf}$ ) foam. All samples were cut into 8" $\times 8$ " $\mathrm{x} 2$ " dimensions by Foam Distributor, Inc (Hayward, CA), and were stored at ambient temperature and ambient relative humidity until they were used for the experiment. The density of the test specimens was confirmed according to the procedure described in ASTM D-1596 prior to conditioning [3].

The first phase of this study was to determine the conditioning time required for all samples to reach equilibrium. This was achieved by using a Missimers FT4-100X350 temperature chamber to condition all three cushioning samples, EPU, EPE, and EPS foams, at two extreme temperatures $\left(-17^{\circ} \mathrm{C}\right.$ and $\left.43^{\circ} \mathrm{C}\right)$. The temperature range was selected to represent the most realistic temperature conditions that a product-package system may experience in an actual distribution cycle. ASTM D-4332 "Conditioning Containers, Packages, or Packaging Components for Testing" was used as a reference [3]. The temperature was measured via a temperature recording system using " $T$ " type thermocouples inserted into the center of each sample block every 30 minutes for 15 hours. It was observed that all three cushioning materials reached their respective equilibrium temperature after two hours. 
The temperature changes in the samples after removing them from the chamber was also recorded using the same method. This was done in order to investigate the respective temperature holding time. Temperature decay was observed in the samples immediately after removing them from the chamber. It was therefore determined that the shock test needed to be performed within 30 seconds after extracting the samples from the chamber in order to measure consistent and accurate data. Since these cushioning samples are not hydrophilic, relative humidity was not controlled.

For shock testing, ASTM standard D-1596, "Standard Test Method for Dynamic Shock Cushioning Characteristics of Packaging Material", was employed [3]. A drop height of 30 inches was used for all sample specimens. This is one of the most common drop heights used not only in the industry, but also in the performance testing standard by International Safe Transit Association (ISTA) [4] [6] [8]. The impact velocity was measured just before impact to determine the effects of friction caused by the guiding rods of the shock test equipment. Using this information, the tester was adjusted to achieve the optimum condition equivalent to a free fall drop from 30 inches. The impact velocity was calculated using the formula:

$$
V=\sqrt{2^{*} g^{*} h}
$$

where $V=$ impact velocity (in/s), $g=$ acceleration of gravity $\left(386.4 \mathrm{in} / \mathrm{s}^{2}\right)$, and $\mathrm{h}=\mathrm{a}$ drop height of 30 inches. With a fixed drop height (30"), the releasing mechanism was adjusted and constantly monitored to produce a consistent impact velocity of $152.3 \mathrm{in} / \mathrm{s}$.

Fourteen specimens of each of the three materials were conditioned at four different discrete temperatures $\left(-17^{\circ} \mathrm{C}, 3^{\circ} \mathrm{C}, 23^{\circ} \mathrm{C}\right.$, and $\left.43^{\circ} \mathrm{C}\right)$ for a period of at least 10 
hours prior to the shock test in order to ensure absolute equilibrium. Each specimen was subjected to an impact within 30 seconds after removing the specimen from the chamber. Since the temperature of the specimens changed dramatically once removed from the chamber, only the data from the first impact were recorded. The five static loading conditions for each specimen were selected, dependent on the material and the temperature, in such a way that the chosen static loading conditions were able to generate the concave portion of the cushion curve. Of the five static loadings, the impacts at the three static loadings immediately surrounding the lowest point on the cushion curve were repeated four times to ensure the repeatability of the data. This is because the lowest point, which represents the least deceleration (g) transmitted through the cushion, is the most important when designing protective packaging that attenuates mechanical shock. In order to obtain the cushion curve, some of the EPE and EPS specimens had to be cut into 7" $\times 7$ " $\times 2$ " and 6" $\times 6$ " $\times 2$ " dimensions to create static loadings of more than 1.2 psi and 1.5 psi respectively. This was necessary due to the limitation of available weights needed to create the desired static loadings on the samples of $8^{\prime \prime} \times 8^{\prime \prime} \times 2$ " dimensions. This modification is allowed by the ASTM D-1596 test method [3].

The testing was conducted using a LAB Model SD-10 cushion tester, configured with a GHI transient capture and analysis system that acquired the response data. The response data were received from a Kistler model 8622 piezoelectric accelerometer attached to the dropping mass. The complete shock pulse, in the form of a timeacceleration curve, was obtained only once and during the first impact. Signal filtration was done for each output at $500 \mathrm{~Hz}$ (low-pass filter). 
After construction of cushion curves, the relationship of the minimum deceleration point and respective static loading was investigated at four different temperatures on the cushion curves. The formulae for predicting an optimum static loading and a minimum deceleration for a given temperature were also obtained by bestfit linear regression lines between temperature and static loading, as well as between temperature and minimum deceleration. The effect of temperature on both transmitted deceleration and static loading was then quantified by obtaining the correlation coefficient of the best-fit regression lines.

\section{DATA AND RESULTS}

\section{Cushion Curves}

The transmitted deceleration versus static loading for the first impact of each sample material at four temperatures was plotted as cushioning curve. The data used for analysis was taken from the lowest point in each curve

The cushion curves for the EPU foam (1.8pcf, 95ILD), at four different temperatures, are displayed in figure 1. The results indicated that temperature influenced the deceleration level. The lowest point in the curve was found to be between $0.18 \mathrm{psi}$ and 0.22 psi. The static loading range was small, and the deceleration levels were slightly different. A relationship was observed whereby higher conditioning temperatures resulted in less deceleration being transmitted during impact. 
The cushion curves for the EPE foams (Ethafoam 220, 2.2pcf), as shown in figure 2 , indicate that there was a difference both in transmitted deceleration levels and the static loadings where these occurred over the four temperatures. Unlike the EPU foam, when the EPE foam specimens were conditioned at higher temperatures, both the minimum transmitted deceleration and the static loadings where these occurred tended to be slightly higher.

The cushion curves for all EPS foam (1.0pcf) samples over the four temperature levels are displayed in figure 3. All EPS foam samples had approximately the same minimum transmitted deceleration level of $40 \mathrm{~g}$, but the static loadings where these minimum decelerations occurred differ slightly.

\section{Formulae of Best-fit Regression Lines}

Analysis was then performed on the EPE and EPU foams' results to quantify the effect of temperature on both the minimum transmitted deceleration and static loading where these occurred. For EPE foams, there was a strong relationship between temperature and minimum deceleration, by using a best-fit linear regression line, with a correlation coefficient $(R)$ of 0.99 . There was also a strong relationship $(R=-0.90)$ between temperature and static loading. The best-fit regression lines for these two relationships are shown in figures 4 and 5 . The following formulae describe these relationships:

$$
\begin{aligned}
& D=0.148 T+35.48 \\
& S=-0.0087 T+1.14
\end{aligned}
$$


where $\mathrm{T}$ is a temperature $\left({ }^{\circ} \mathrm{C}\right)$ ranging between $-17^{\circ} \mathrm{C}$ and $43^{\circ} \mathrm{C}, \mathrm{D}$ is the minimum transmitted deceleration (g), and S is static loading (psi) where these minimum occurred. These formulae indicate that a temperature increase of $10^{\circ} \mathrm{C}$ decreases the minimum transmitted deceleration by $1.48 \mathrm{~g}$ and the static loading where these occurred by approximately 0.09 psi.

With regards to EPU foams, a very strong correlation $(R=-1.0)$ was found between temperature and minimum transmitted deceleration by using the third order polynomial fit. There was also a strong correlation $(R=-0.94)$ observed between temperature and static loading by using the second order polynomial fit. The best-fit regression lines for the EPU foam are shown in figures 6 and 7. The following formulae describe these relationships at the temperature ranges tested $\left(-17^{\circ} \mathrm{C}\right.$ to $\left.43^{\circ} \mathrm{C}\right)$ :

$$
\begin{aligned}
& \mathrm{D}=6.25 \mathrm{E}^{-6} \mathrm{~T}^{3}+2.32 \mathrm{E}^{-3} \mathrm{~T}^{2}-0.22908 \mathrm{~T}+35.46621 \\
& \mathrm{~S}=1.4375 \mathrm{E}^{-5} \mathrm{~T}^{2}-8.8875 \mathrm{E}^{-4} \mathrm{~T}+0.19369
\end{aligned}
$$

\section{DISCUSSION}

The relationships between the minimum transmitted deceleration and the respective static loading for EPU (1.8pcf, 95ILD), EPS (1.0pcf), and EPE (Ethafoam 220, 2.2pcf) foams, are summarized in figure 8 , with the arrow indicating the direction of temperature increase. A previous study on EPE foam (Ethafoam 220) at other temperatures and drop heights indicated the same trend observed in this study [4]. It can be observed from this graph that there was a minimum effect of temperature on the EPS 
foam performance. In contrast, for EPU and EPE foams, temperature had a significant influence both on the minimum transmitted deceleration and the static loading at which the minimum deceleration occurred.

One possible reason why the EPS foam was not significantly affected by temperature is that it is a non-elastic material and was brittle (non-flexible) within the temperature range tested $\left(-17^{\circ} \mathrm{C}\right.$ to $\left.43^{\circ} \mathrm{C}\right)$, which was lower than the glass transition temperature of the EPS foam [5] [9].

The effect of temperature on the minimum deceleration for the EPU foam was basically the opposite of the effect on the EPE foam. There was a positive relationship between minimum transmitted deceleration and temperature for the EPE foam, while a negative relationship was observed for the EPU foam. This difference is related to their structural differences. Since the EPU foam is an open-cell foam, it absorbs energy (shock) by releasing air from inside the cells [5]. At higher temperatures, due to higher molecular movement, it becomes easier for the EPU foam to release more air outside. In other words, the EPU foam can absorb more energy at higher temperatures, i.e., less transmitted deceleration at higher temperature. The EPE foam is a closed-cell foam, which absorbs energy by compressing the air trapped inside the cells [5]. At lower temperatures, the cells shrink allowing the structure to become more flexible, which means the EPE foam can absorb more energy at lower temperatures, i.e., less transmitted deceleration at lower temperature.

The limitations in this study are that the tests were conducted within a temperature range of $-17^{\circ} \mathrm{C}$ to $43^{\circ} \mathrm{C}$. Hence, inference or generalization of the shock 
absorption properties' changes for EPU, EPE, and EPS foams at temperatures not covered within this range may not be valid. Furthermore, the results found in this study are applicable only to cushioning materials with a two-inch thickness and densities comparable to those used in this study. The results may differ for cushioning materials with different thickness and densities.

\section{CONCLUSIONS}

We observed that the shock absorption properties of EPU (1.8pcf) and EPE (Ethafoam 220, 2.2pcf) foams significantly varied with various temperatures. Formulae for indicating these relationships were derived using a regression model. The EPU foam transmitted less deceleration shock (approximately $30 \mathrm{~g}$ ) with lower static loading $(0.18$ psi) and a higher temperature $\left(43^{\circ} \mathrm{C}\right)$, while displaying higher transmitted deceleration $(40 \mathrm{~g})$ at a lower temperature $\left(-17^{\circ} \mathrm{C}\right)$. The EPE foam, in comparison, showed more transmitted deceleration $(42 \mathrm{~g})$ with lower static loading ( $0.83 \mathrm{psi})$ and a higher temperature, and less transmitted deceleration (33g) with a lower temperature. Regarding the EPS foam, no notable temperature effect was found in the temperature ranges tested $\left(-17^{\circ} \mathrm{C}\right.$ to $\left.43^{\circ} \mathrm{C}\right)$.

Since temperature fluctuation is very common in the distribution environment, these results can be used as a model for the cushioning design or confirmation of protective packaging. In particular, the derived formulae can be used as an aid in predicting static loading and minimum transmitted deceleration for EPU and EPE foams. 
It may not be pragmatic to require consideration of temperature effects on shock absorption if temperature variations of less than $10^{\circ} \mathrm{C}$ are expected, because within this range there was only a relatively small difference (less than $12 \%$ ) in minimum transmitted deceleration and static loading.

\section{ACKNOWLEGEMENT}

The authors would like to thank Foam Distributors, Inc. of Hayward, CA, for donating the cushioning materials used in this study. We also would like to thank Westpak, Inc. of San Jose, CA for usage of their facilities for this research. 


\section{REFERENCES}

1. W. Soroka, Fundamentals of Packaging Technology. Institute of Packaging Professionals, Herndon (1995).

2. C. M. Harris, Shock and Vibration Handbook. McGraw-Hill, New York (1988).

3. Selected ASTM Standards on Packaging, American Society for Testing and Materials, Philadelphia (1994).

4. Product and Design Data, Dow Chemical U.S.A., Midland (1987).

5. G. J. Burgess, Technical Principals and Dynamics for Packaging Class Notes, Michigan State University, East Lansing (1993).

6. T. L. Totten, G. J. Burgess, and S. P. Singh, Packaging Technology and Science, 3, $117-122(1990)$.

7. S. W. Lye, M. Y. Teo, and S. C. Lew, Journal of Material Engineering and Performance, 4(3), 308-313 (1995).

8. Preshipment Test Procedures, International Safe Transit Association, East Lansing (1996).

9. A. Elboudwarej, Packaging Materials-Plastic for Packaging Class Notes, San Jose State University, San Jose (1997). 
Titles of figures:

Figure 1. Cushion curves for EPU foam at various temperatures (30" drop height, $1^{\text {s }}$ Impact)

Figure 2. Cushion curves for EPE foam at various temperatures (30" drop height, $1^{\text {st }}$ Impact)

Figure 3. Cushion curves for EPS foam at various temperatures (30" drop height, $1^{\text {s }}$ Impact)

Figure 4. Relationship between temperature and deceleration of EPE foam

Figure 5. Relationship between temperature and static loading of EPE foam

Figure 6. Relationship between temperature and deceleration of EPU foam

Figure 7. Relationship between temperature and static loading of EPU foam

Figure 8. Relationship of minimum deceleration, static loading, and temperature (30" drop height, $1^{x}$ Impact) 


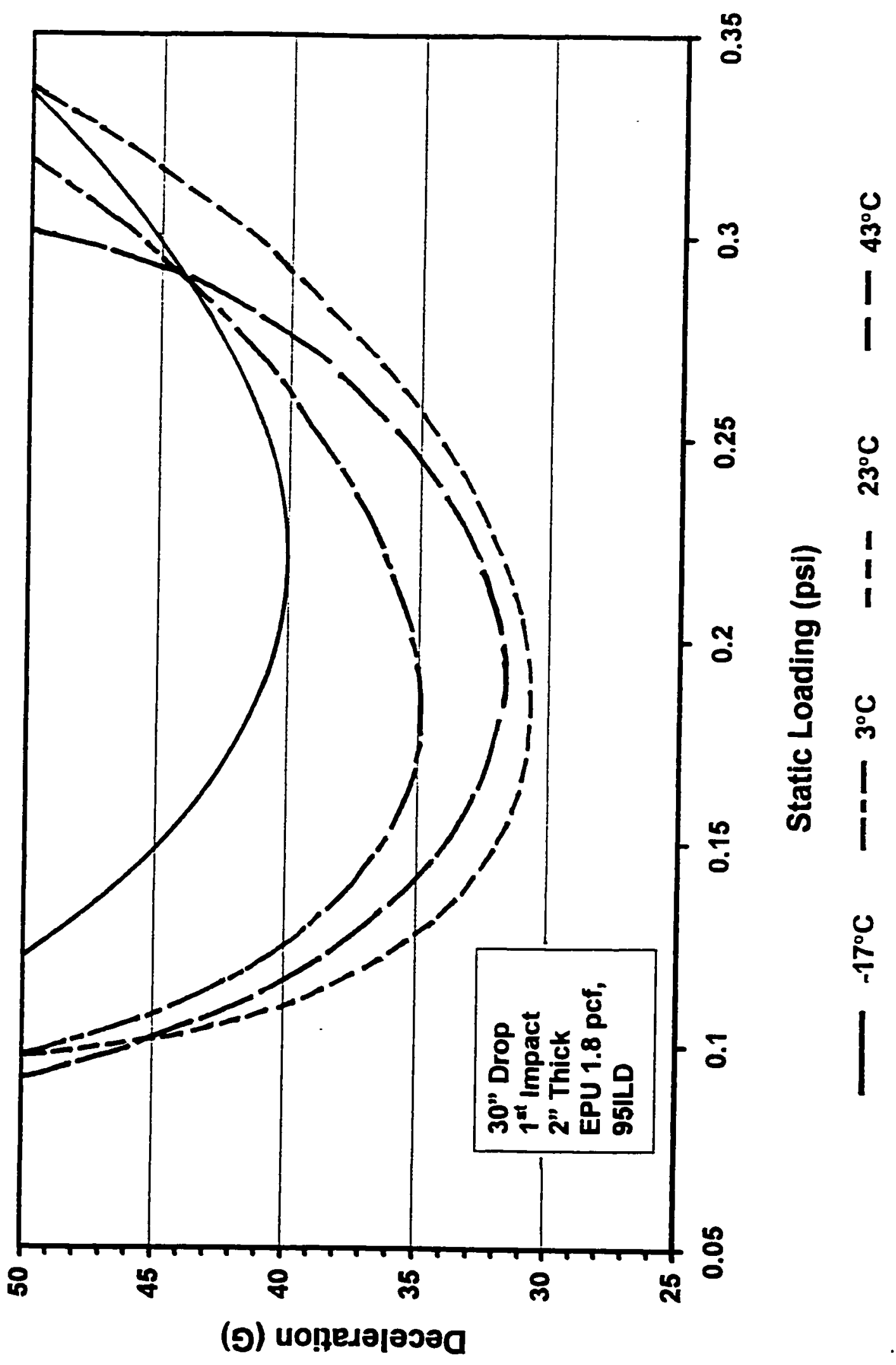




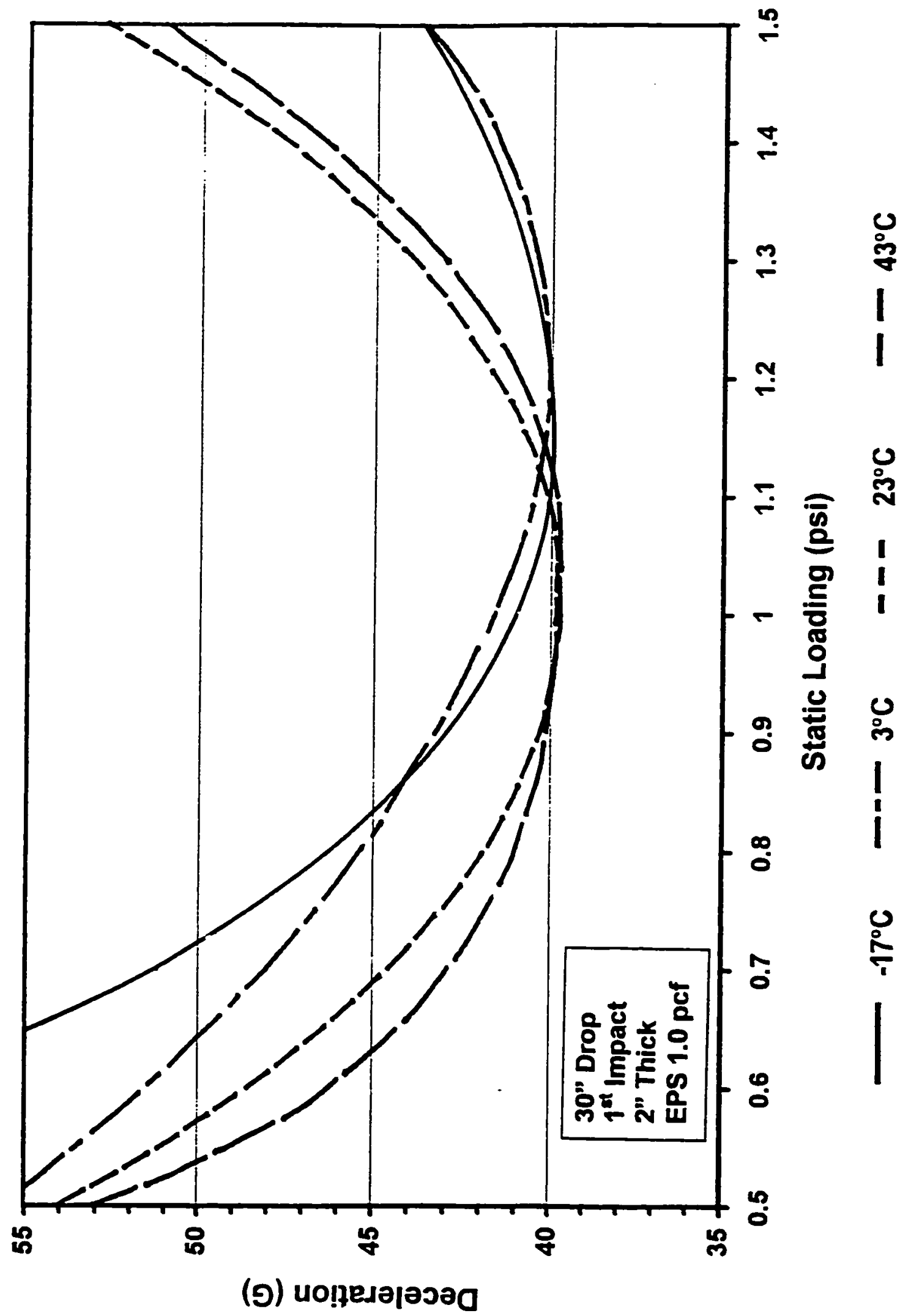




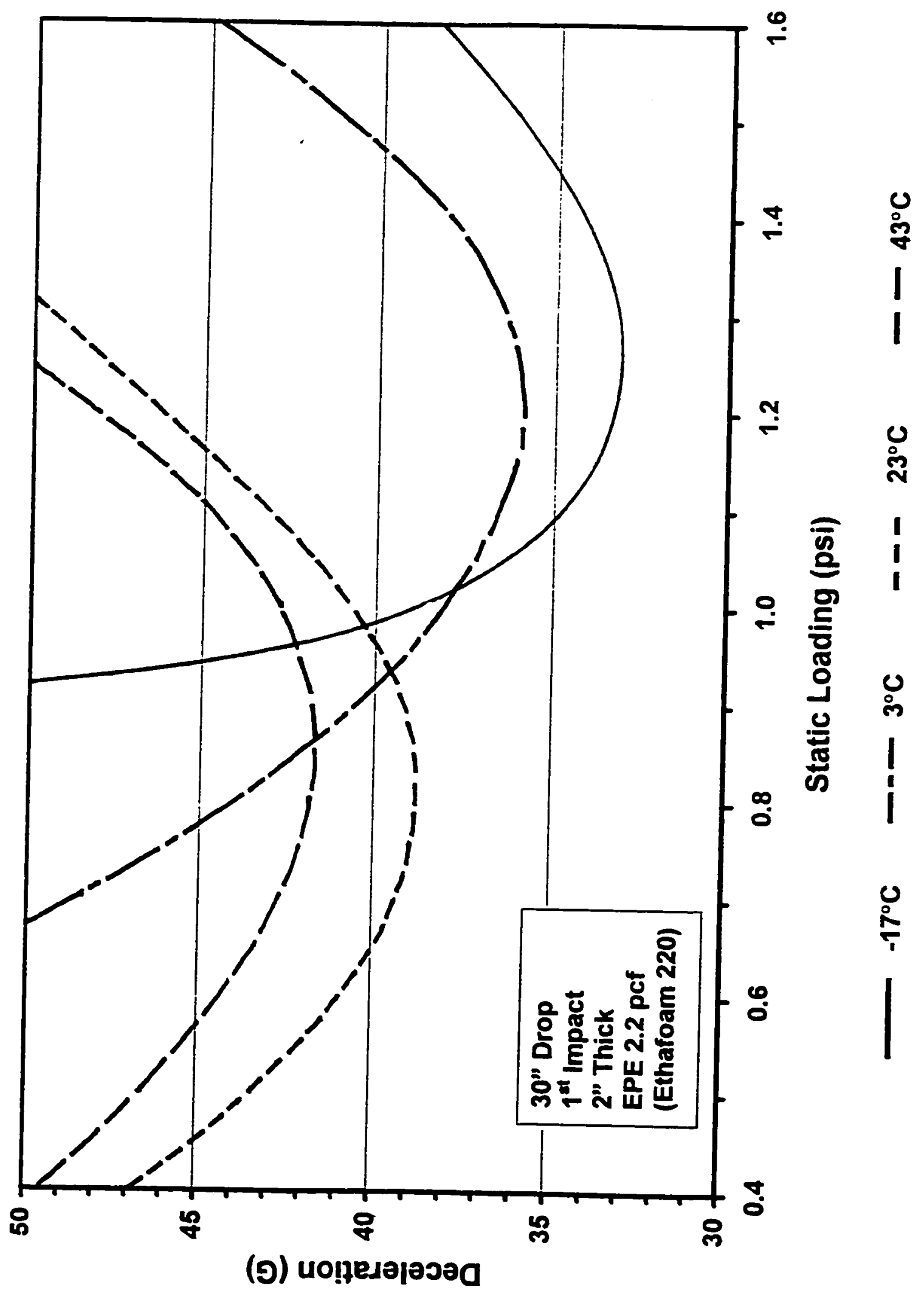


EPE: Relationship between Temperature \& Deceleration $D=0.148 T=35.48 \quad(R=0.99)$

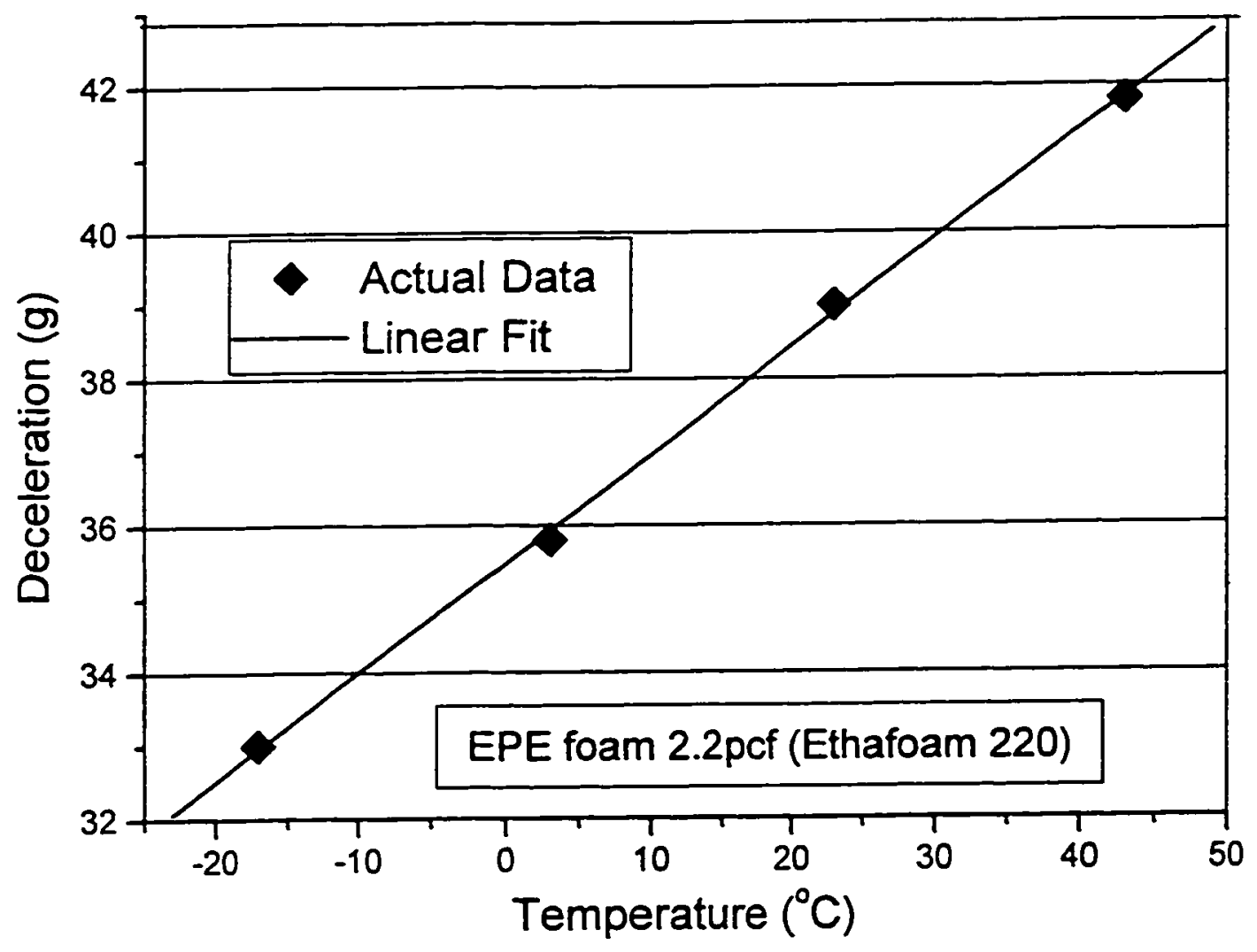


EPE: Relationship between Temperature \& Static Loading $S=-0.0087 T+1.14 \quad(R=0.90)$

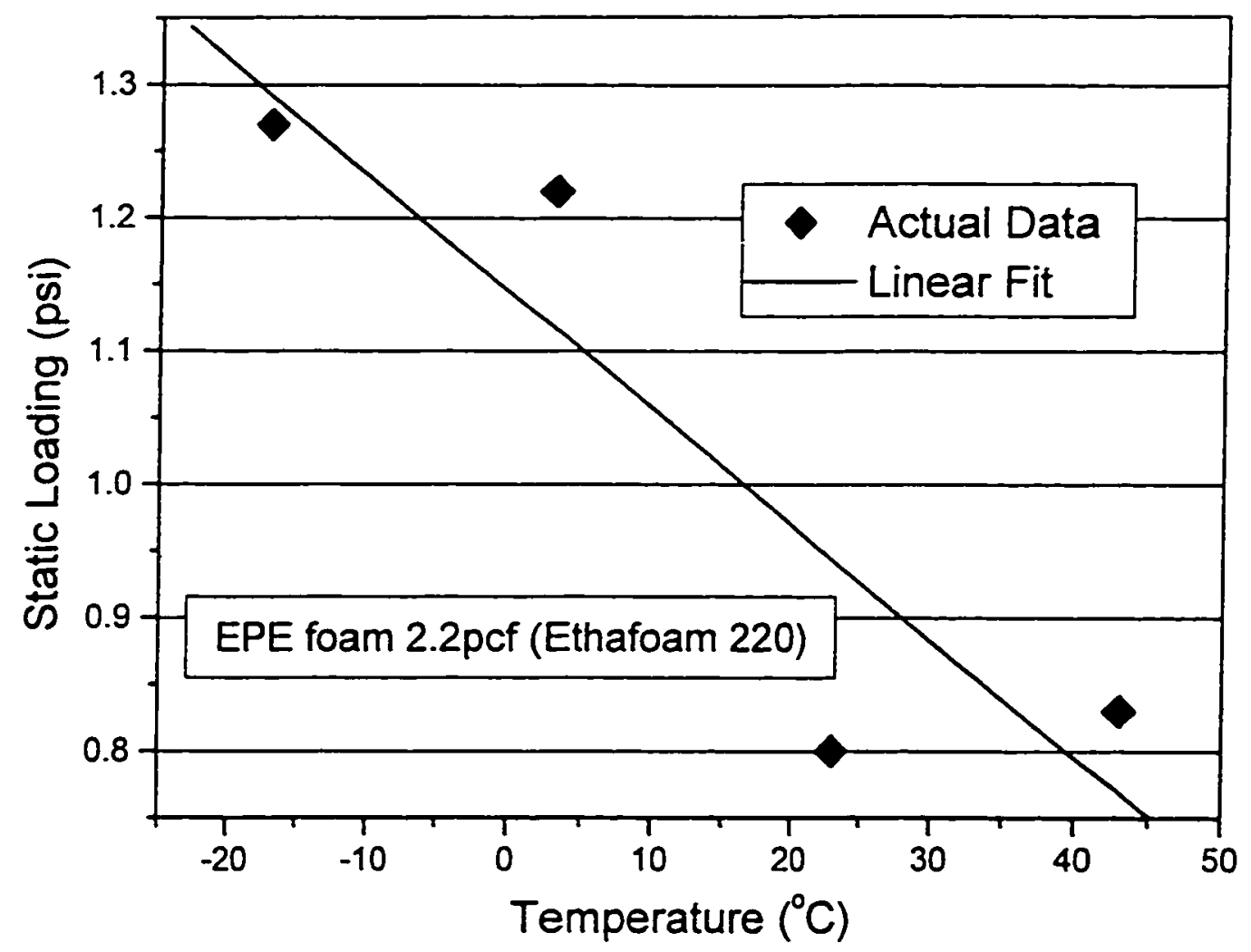


EPU: Relationship between Temperature \& Deceleration

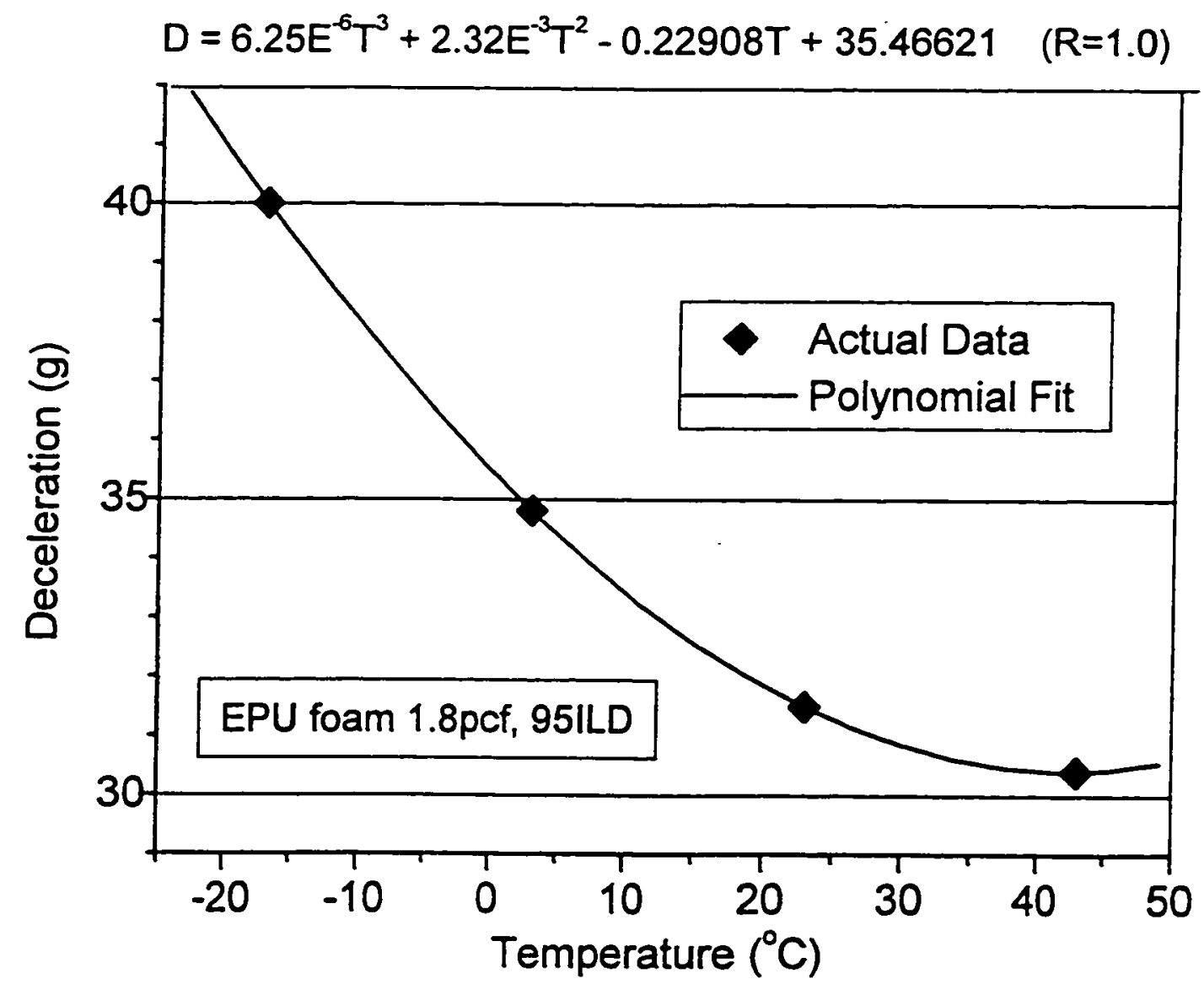


EPU: Relationship between Temperature \& Static Loading $S=1.4375 E^{-5} T^{2}-8.8875 E^{-4} T+0.19369 \quad(R=0.94)$

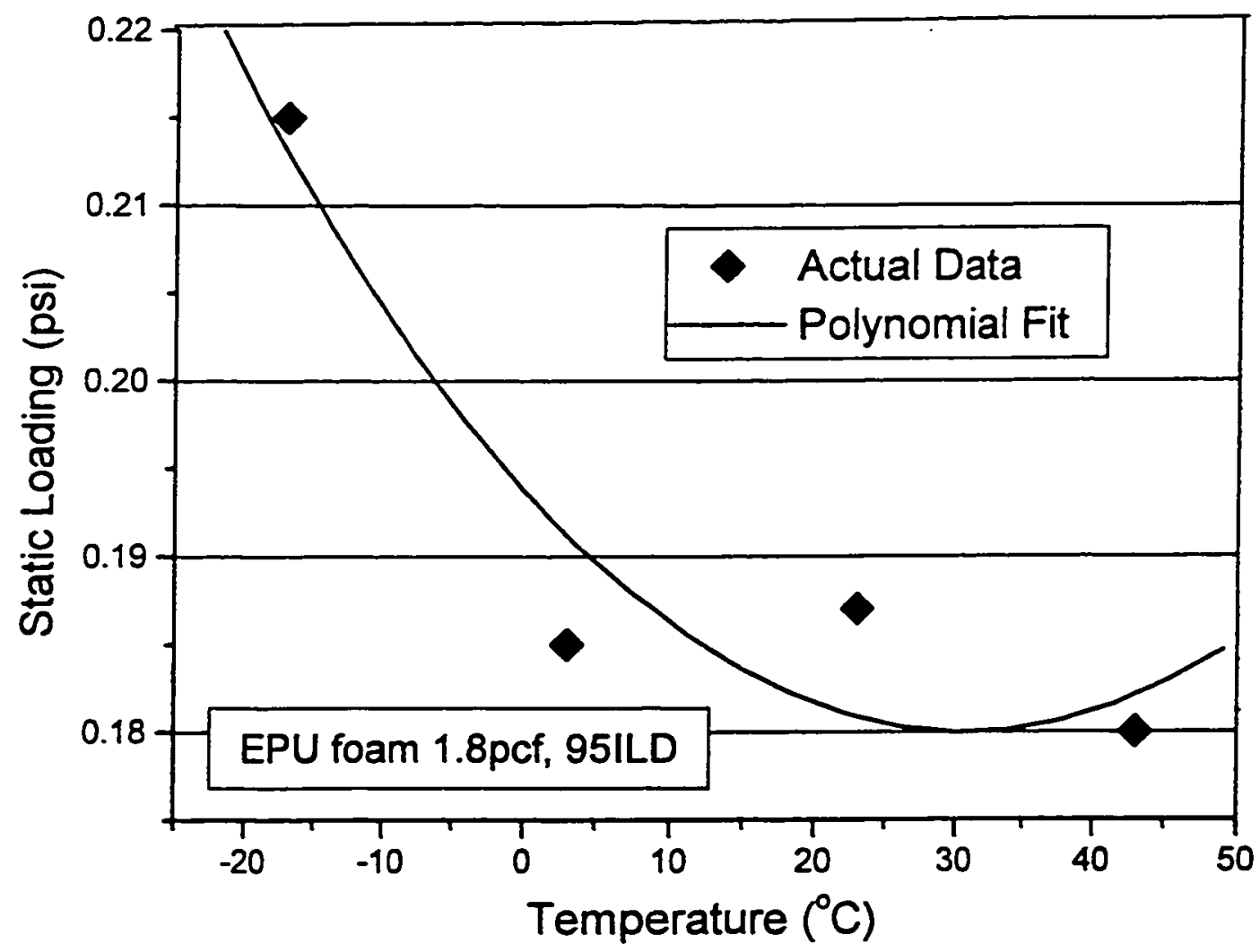




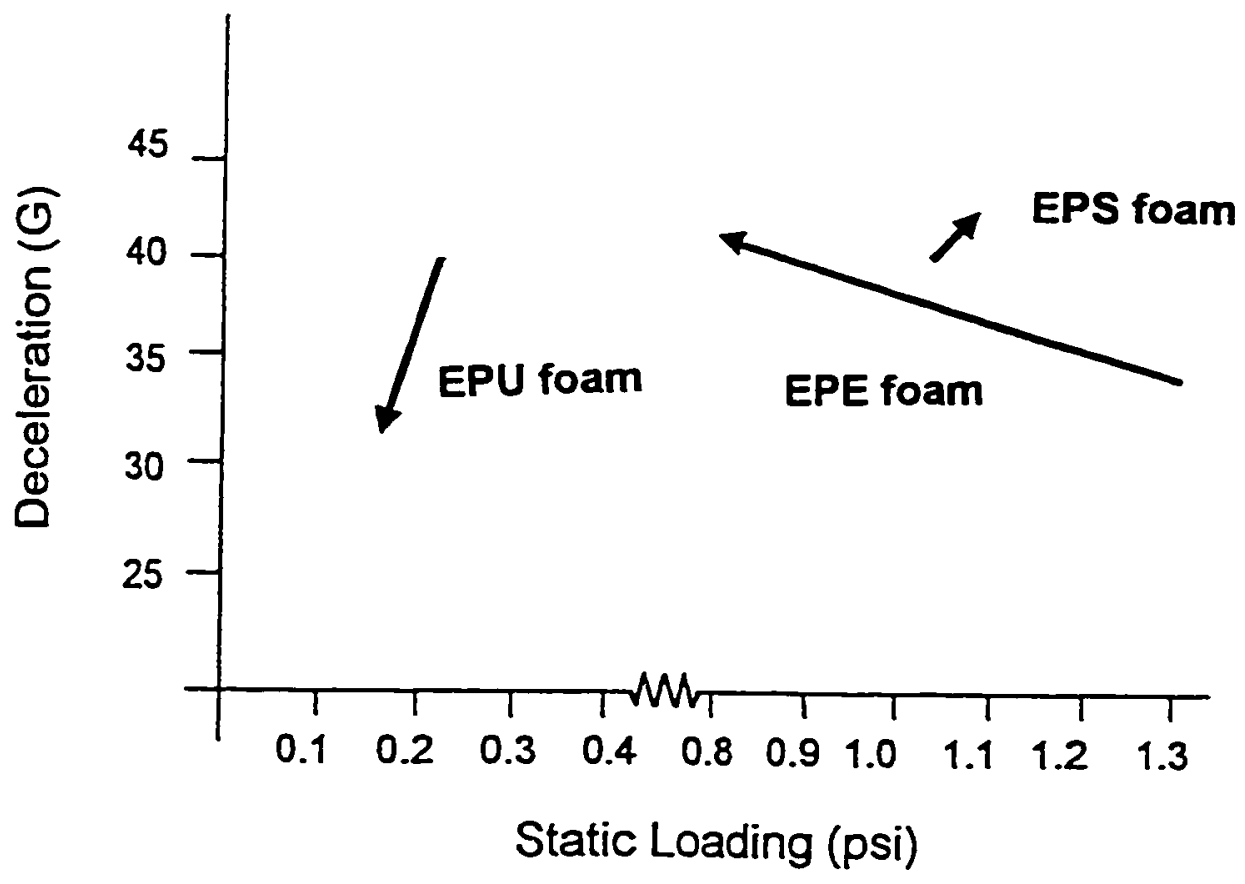




\section{CHAPTER 3 \\ SUMMARY AND RECOMMENDATIONS}

\section{Summary}

The temperature effect on shock absorption properties was investigated for three of the most commonly used cushioning blocks: EPU (1.8pcf, 95ILD), EPS (1.0pcf), and EPE (2.2pcf, Ethafoam 220) foams. Cushion curves of these three materials tested at four different discrete temperatures $\left(-17^{\circ} \mathrm{C}, 3^{\circ} \mathrm{C}, 23^{\circ} \mathrm{C}\right.$, and $\left.43^{\circ} \mathrm{C}\right)$ from a drop height of 30 inches were obtained by testing cushioning blocks in accordance with ASTM D-1596 standard test method. Since the temperature of the specimens changed dramatically once the samples were removed from the chamber, only the data point from the first impact, within 30 seconds of removal, was recorded. Pilot testing demonstrated that this duration was sufficient to maintain the conditioning temperatures of all three cushioning materials.

In order to ensure complete equilibrium, the fourteen specimens for each of the three materials were conditioned at four different discrete temperatures for a period of at least 10 hours prior to the experiment. To minimize the specimen's temperature change, each specimen was subjected to an impact within 30 seconds after removing the specimen from the chamber. The five static loading conditions for each specimen were selected, dependent on the material and the temperature, in such a way that the chosen static loading conditions were able to generate the concave portion of the cushion curve. Of the five static loadings, the impacts at the three static loadings immediately surrounding the lowest point on the cushion curve were repeated four times to ensure the repeatability of the data. This is because the lowest point, which represents the least 
deceleration ( $\mathrm{g}$ ) transmitted through the cushion, is the most important when designing protective packaging that attenuates mechanical shock.

Results revealed that the shock absorption properties of EPU and EPE foams varied with temperature. The EPU foam transmitted less deceleration shock (approximately $30 \mathrm{~g}$ ) with lower static loading (0.18 psi) and a higher temperature $\left(43^{\circ} \mathrm{C}\right)$, while displaying higher transmitted deceleration $(40 \mathrm{~g})$ at a lower temperature $\left(-17^{\circ} \mathrm{C}\right)$. The EPE foam, in comparison, showed more transmitted deceleration (42g) with lower static loading (0.83 psi) and a higher temperature, and less transmitted deceleration ( $33 \mathrm{~g})$ with a lower temperature. Regarding the EPS foam, no notable temperature effect was found in the temperature ranges tested $\left(-17^{\circ} \mathrm{C}\right.$ to $\left.43^{\circ} \mathrm{C}\right)$. One possible explanation why the EPS foam was not notably affected by temperature is that it is a non-elastic material and was brittle (non-flexible) within the temperature range tested $\left(-17^{\circ} \mathrm{C}\right.$ to $\left.43^{\circ} \mathrm{C}\right)$, which was lower than the glass transition temperature of the EPS foam.

Analysis was performed on both the EPU and EPE foams to derive formulae for predicting loading and minimum transmitted deceleration for a given temperature by using best-fit regression lines. There were negative relationships between static loading and temperature for both EPU and EPE foams with correlation coefficients (R) of -0.90 and -0.94 respectively. The effect of temperature on the minimum deceleration for the EPU foam was basically the opposite of the effect on the EPE foam. There was a positive relationship $(R=0.99)$ between the minimum transmitted deceleration and temperature for the EPE foam, while a negative relationship was observed for the EPU foam $(R=-1.0)$. This difference is related to their structural differences, i.e., open-cell 
(EPU foam) versus closed-cell (EPE foam). At higher temperatures, it becomes easier for EPU foam to release more air outside due to higher molecular movement. In other words, the EPU foam can absorb more energy at higher temperatures, i.e., less transmitted deceleration at higher temperature. With regards to the EPE foam, the cells shrink allowing the structure to become more flexible at lower temperature, which means it can absorb more energy at lower temperatures, i.e., less transmitted deceleration at lower temperature.

\section{Recommendation}

Since temperature fluctuation is very prevalent in the distribution environment, these results can be used as a model for the cushioning design or confirmation of optimum protective packaging. In particular, the derived formulae can be used as an aid in predicting static loading and minimum deceleration for EPU and EPE foams. It may not be pragmatic to require consideration of temperature effects on shock absorption if only variations of within $10^{\circ} \mathrm{C}$ are expected due to the relatively small difference (less than $12 \%$ ) in minimum transmitted deceleration and static loading. The results found in this study are applicable to only EPU, EPE, and EPS foams with a two-inch thickness and densities comparable to those used in this study.

Further studies may be necessary to determine if the formulae derived in this study are still applicable to other temperature ranges or for these same cushioning materials with different thickness or densities. Since the results were different for opencell and closed-cell materials, the effect of temperature on the shock absorption properties of other closed-cell material, expanded polypropylene (EPP) foams, would be 
very interesting to confirm the results of this study. Moreover, the effect of atmospheric pressure on the shock absorption properties of both open-cell and closed-cell foams may also be beneficial to the packaging industry. Finally, knowing the effect of temperature on shock absorption properties of other cushioning materials, such as recycled EPS, loose-fill, and molded pulp, may also be advantageous for the packaging industry to ensure optimum product protection. 


\section{References}

American Society for Testing and Materials. (1994). Selected ASTM standards on packaging ( $4^{\text {th }}$ ed.) Philadelphia, PA: Author.

Bandenburg, R. K., \& Lee, J. J. (1993). Hazards in distribution, In Goff, J. W., Kufahl M. M., Fiedler, R. M., \& Kieskamp, J. (Eds.), Fundamentals of packaging dynamics (5th ed., pp. 1-2), Skaneateles, NY: L.A.B.

Burgess, G. J. (1993). Technical principles and dynamics for packaging. East Lansing, MI: Michigan State University, School of Packaging.

Dow Chemical U. S. A. (1987). Product and design data, [Brochure]. Midland, MI: Author.

Eagleton, D. G., \& Marcondes, J. A. (1994). Cushioning properties of moulded pulp. Packaging Technology and Science, 7, 65-72.

Hanlon, J. F. (1992). Cushioning. In Handbook of package engineering (2nd ed., pp. 16.1-16.10), Lancaster, PA: Technomic Publishing.

Harris, C. M. (1988). Properties of cushioning materials. In H. B. Crowford, D. E. Fogarty \& R. A. Ausburn (Eds.), Shock and vibration handbook (3rd ed., pp.41.1-41.30), New York, NY: McGraw-Hill Book.

Lye, S. W., Teo, M. Y., \& Lew, S. C. (1995). A study of shock characterization for protective packaging design. Journal of Material Engineering and Performance, 4(3), 308-313.

Marcondes, J. A. (1998). Molded pulp cushioning: The need for design standards. Packaging Technology and Engineering. 7(1), 38-85. 
Marcondes, J. A. (1997). Packaging Dynamics Class Notes. San Jose, CA: San Jose State University, Department of Nutrition and Food Science.

Mohareb, N., Homberger, L., Pirie, T., \& Hight, T. (1994). Static properties of recycled EPS. Annual Technical Conference - ANTEC, Conference Proceedings, USA, 2. 2979-2983.

Pirie, T., Hornberger, L., Mohareb, N., \& Hight, T. (1994). Cushion curves of recycled EPS foam. Annual Technical Conference-ANTEC, Conference Proceedings, USA, $3,2975-2978$.

Selke, S. M. (1990). Solid waste. In Packaging and the Environment (pp. 45-51). Lancaster, PA: Technomic Publishing.

Sims, G. A., \& Bennett, J. A. (1995). Package design implications of impact studies on flexible polyurethane foams. Annual Technical Conference - ANTEC, Conference Proceedings, USA, 2, 2197-2201.

Singh, S. P., Chonhenchob, V., \& Burgess, G. (1994). Comparison of various loose fill cushioning materials based on protective and environmental performance. Packaging Technology and Science, 7, 229-241.

Soroka, W. (1995). Shock, vibration, and compression. In Fundamentals of Packaging Technology (pp. 417-442). Herndon, VA: Institute of Packaging Professionals.

Totten, T. L., Burgess, G. J., \& Singh, S. P. (1990). The effects of multiple impacts on the cushioning properties of closed-cell foams. Packaging Technology and Science, 3, 117-122. 


\section{APPENDIX A}

\section{Test Setting}

Figures A.1 to A.4 show how the cushioning specimens were conditioned and tested. Probe in figures A.1 shows how the samples were monitored for temperature changes during the pilot study. 


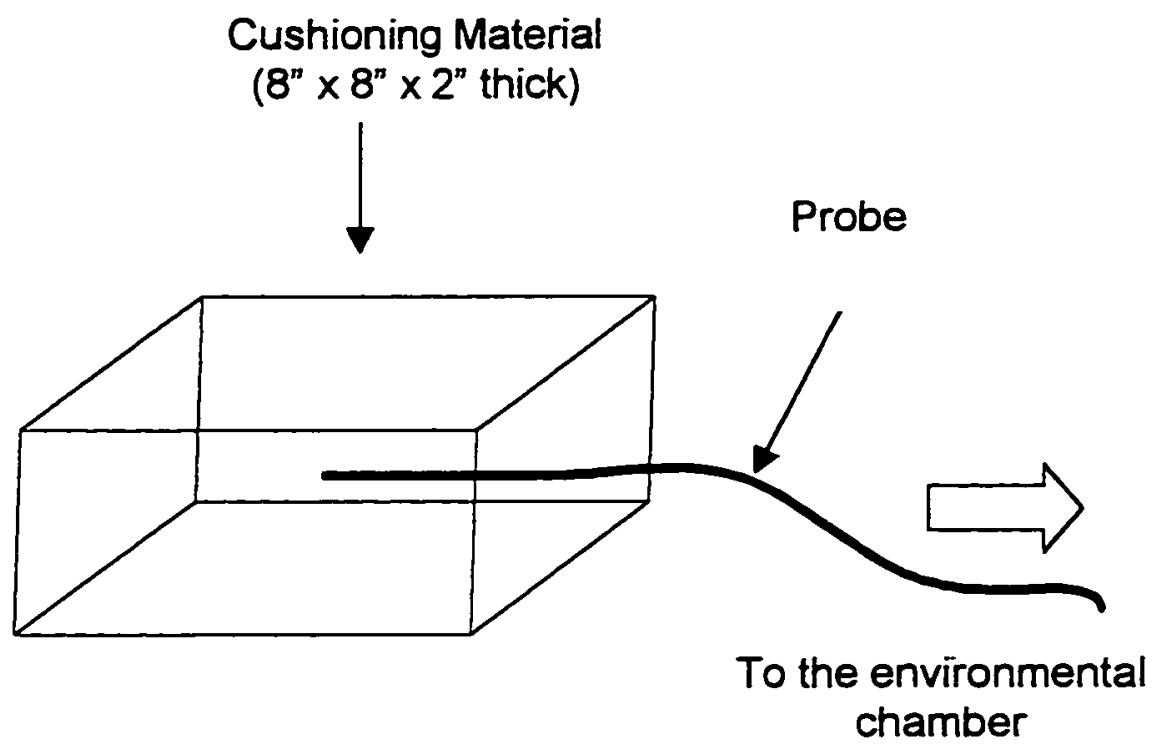

Figure A. 1: Location of probe

("T" type thermocouple) 


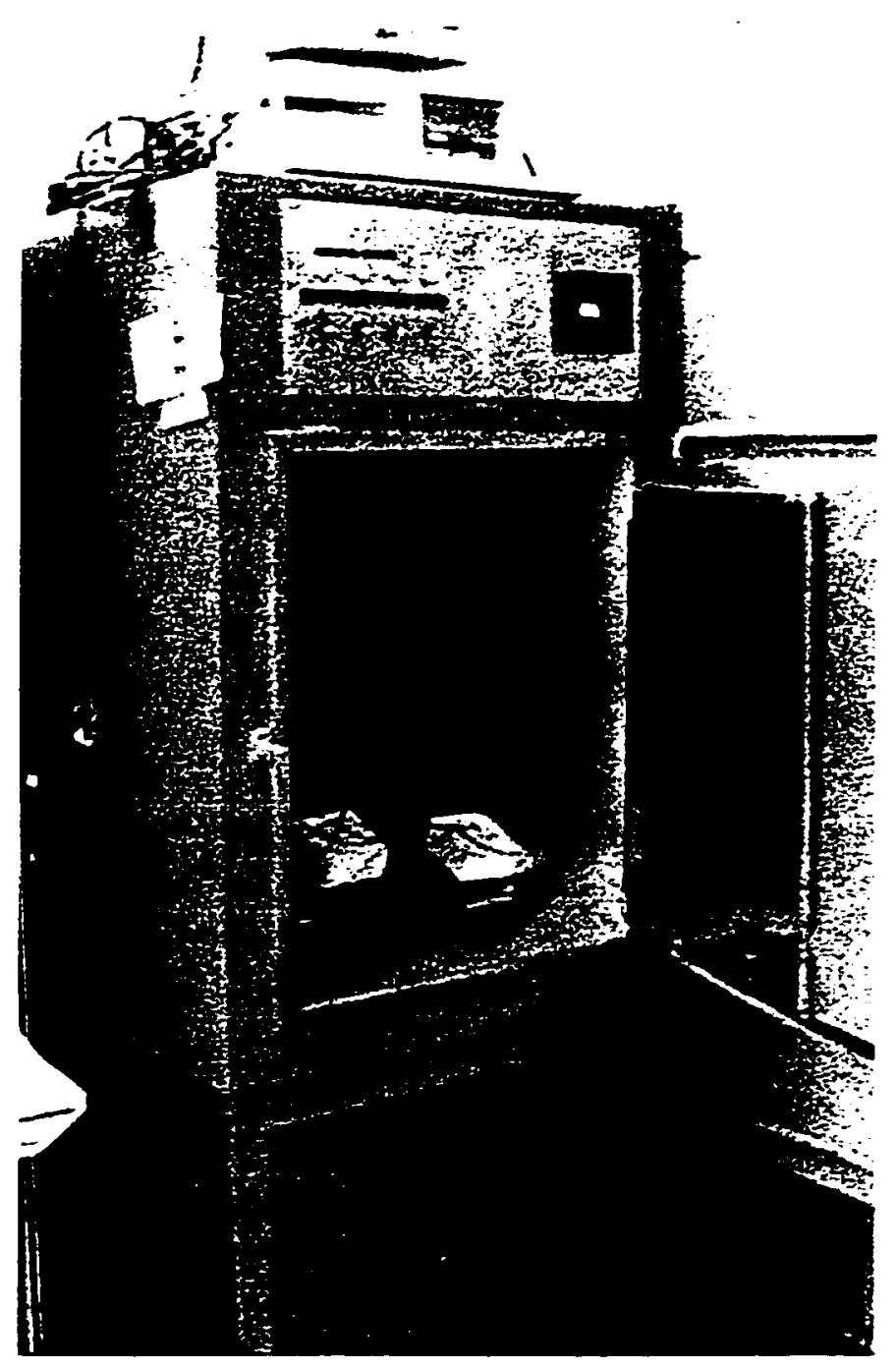

Figure A.2: Temperature chamber 


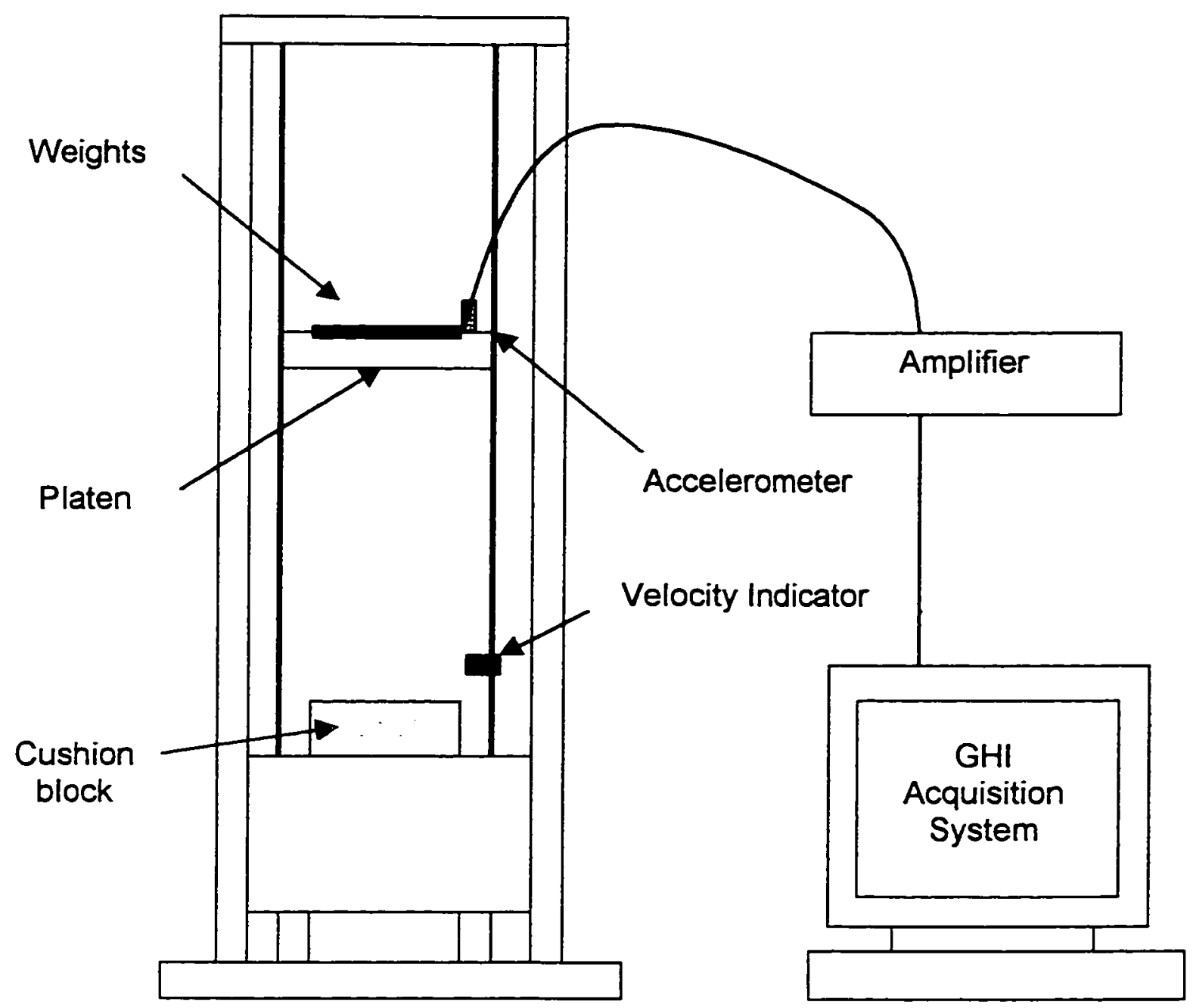

Shock Tester (Lansmont SD-10)

Figure A.3: Testing set-up diagram 


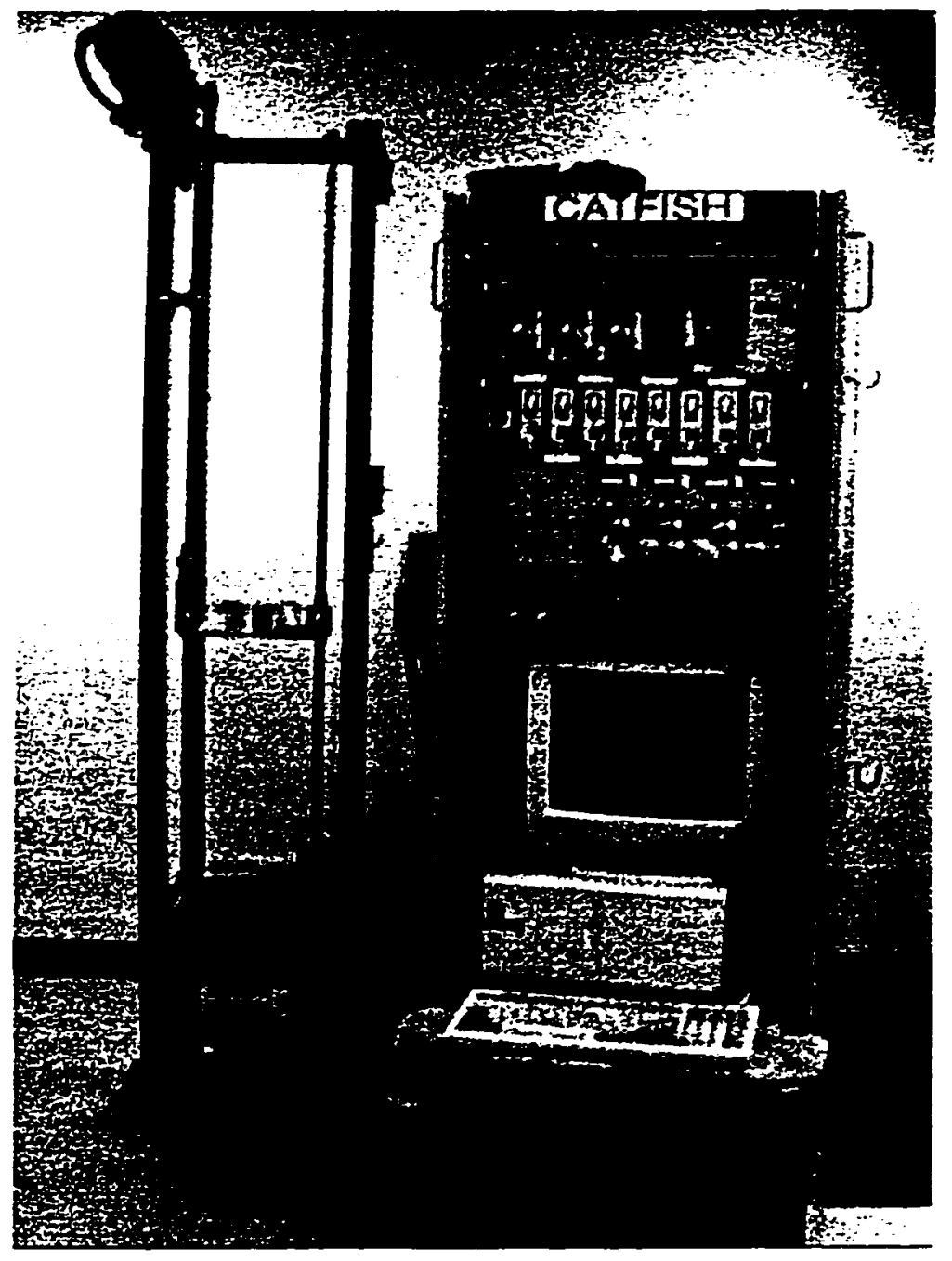

Figure A.4: Testing set-up 


\section{APPENDLX B}

\section{Summary of Pilot Study Results}

Figures B.1 to B.4 show the results of temperature variation during conditioning and after removal from the chamber. 


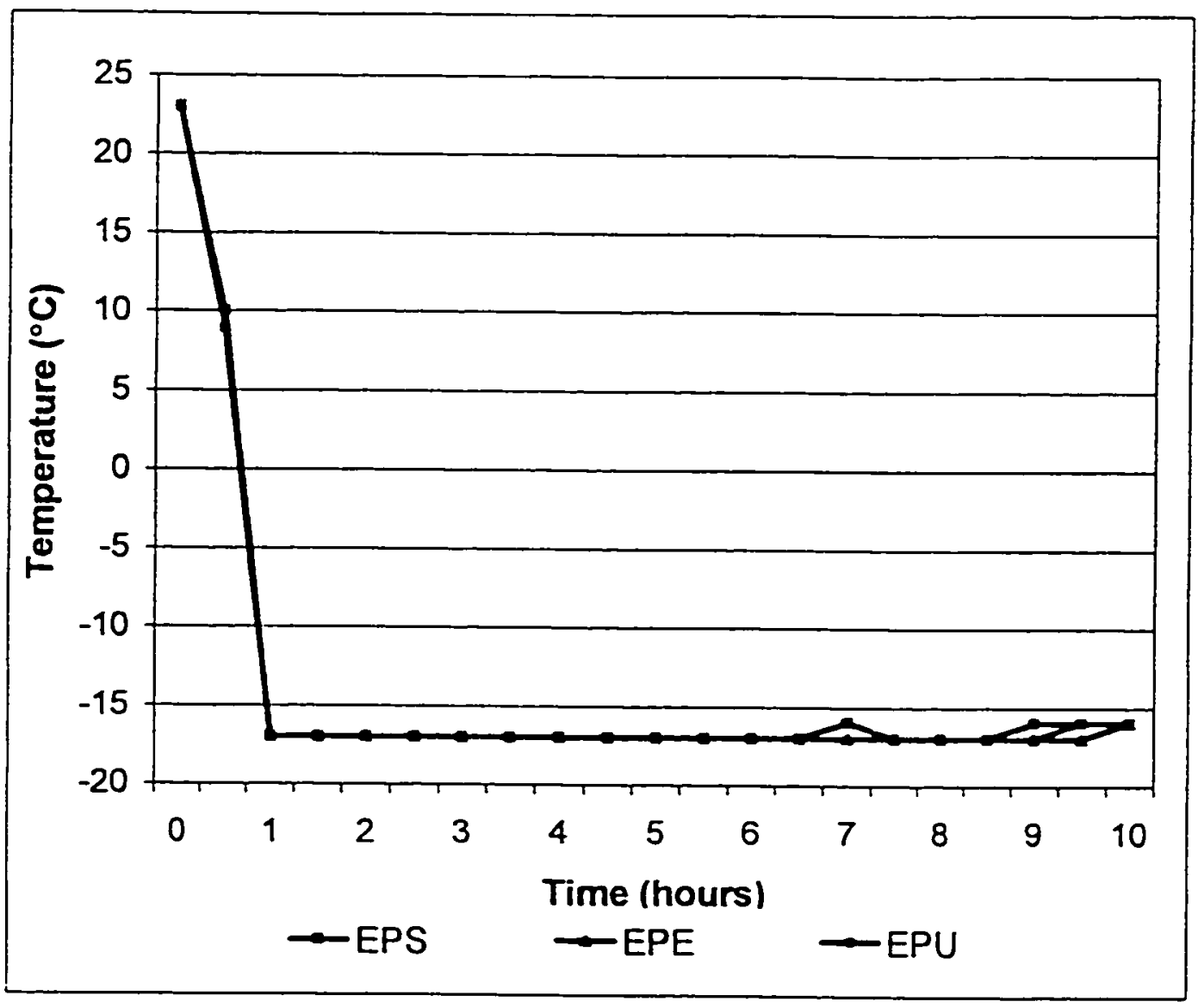

Figure B.1: Conditioning time to reach equilibrium $\left(-17^{\circ} \mathrm{C}\right)$ 


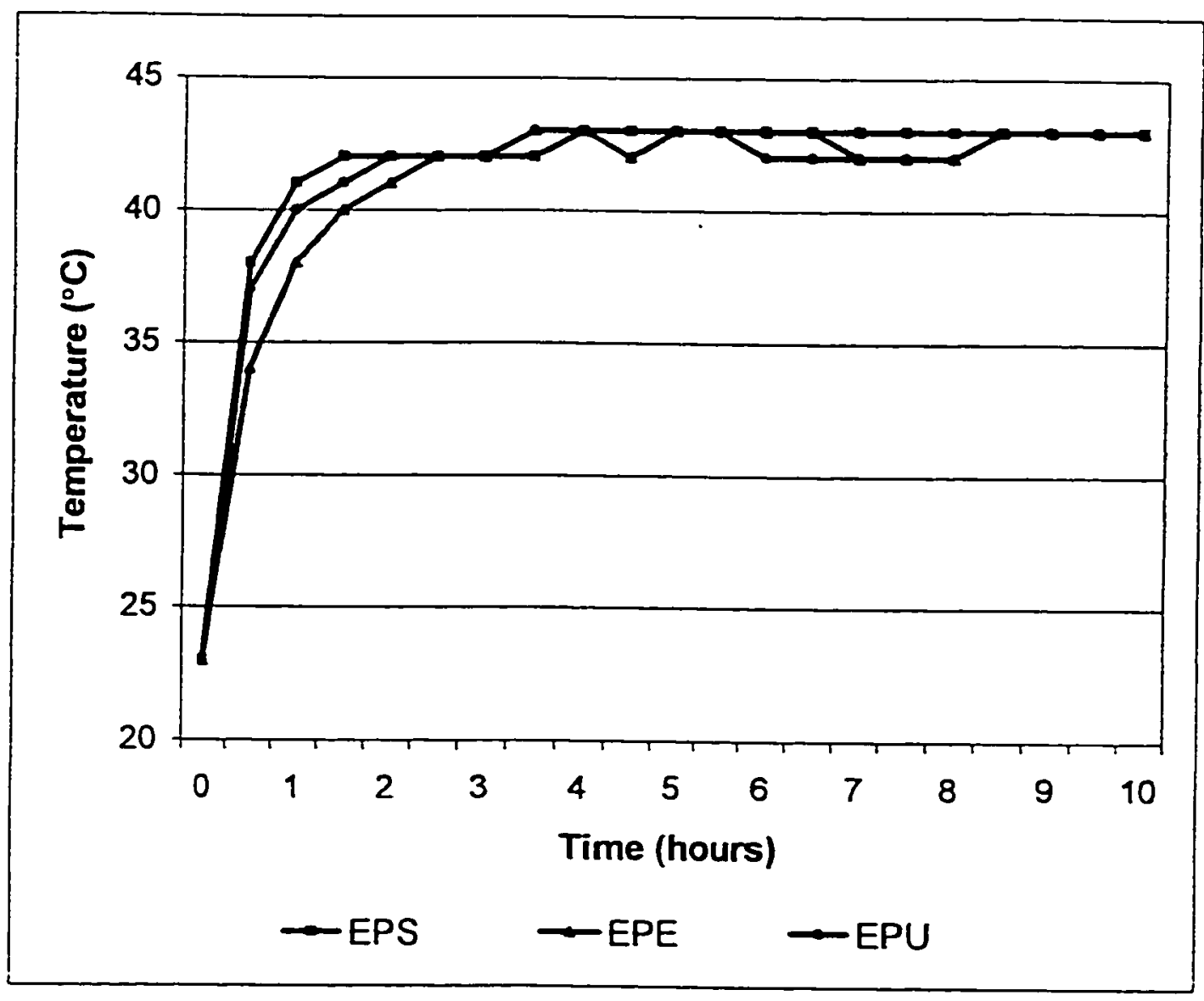

Figure B.2: Conditioning time to reach equilibrium $\left(43^{\circ} \mathrm{C}\right)$ 


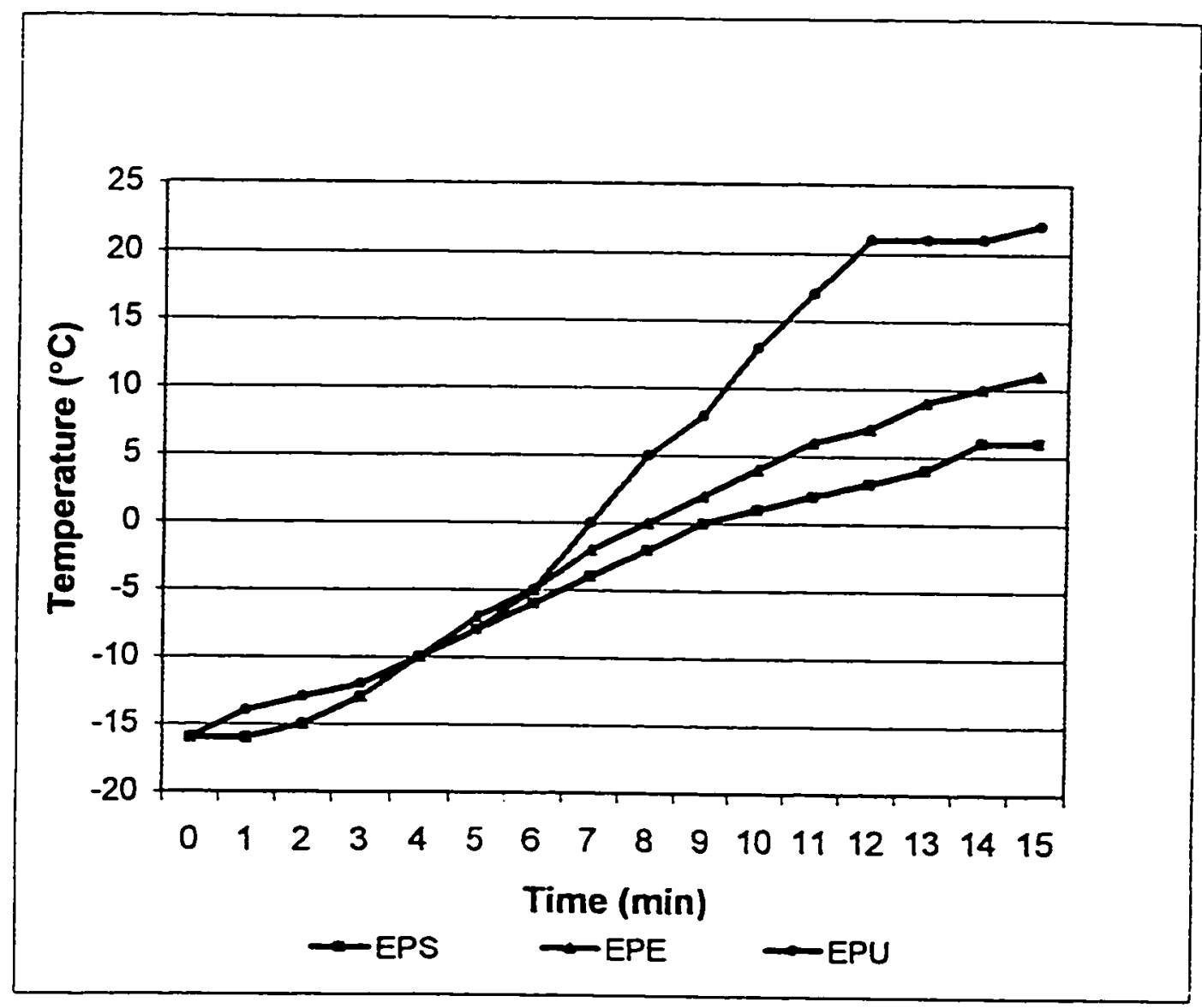

Figure B.3: Temperature change after conditioned at $-17^{\circ} \mathrm{C}$ 


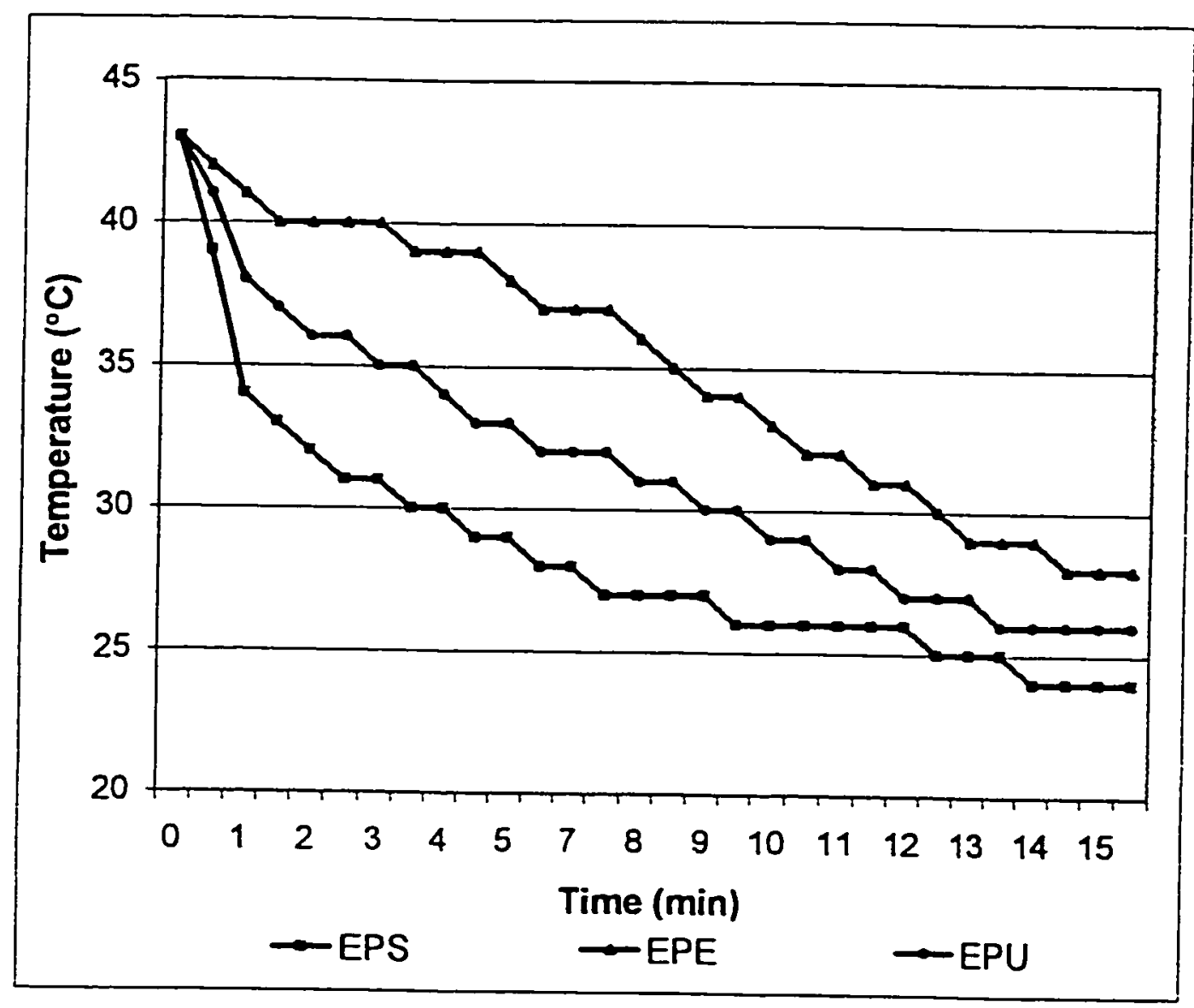

Figure B.4: Temperature change after conditioned at $43{ }^{\circ} \mathrm{C}$ 


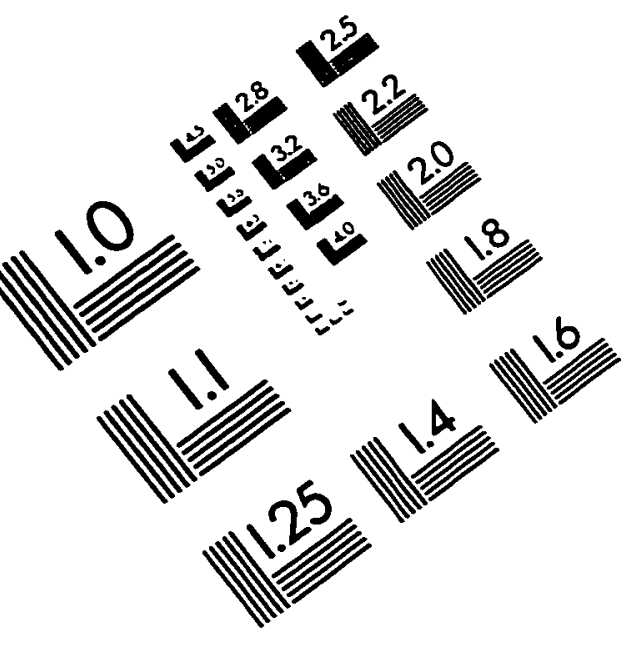

\section{IMAGE EVALUATION \\ TEST TARGET (QA-3)}
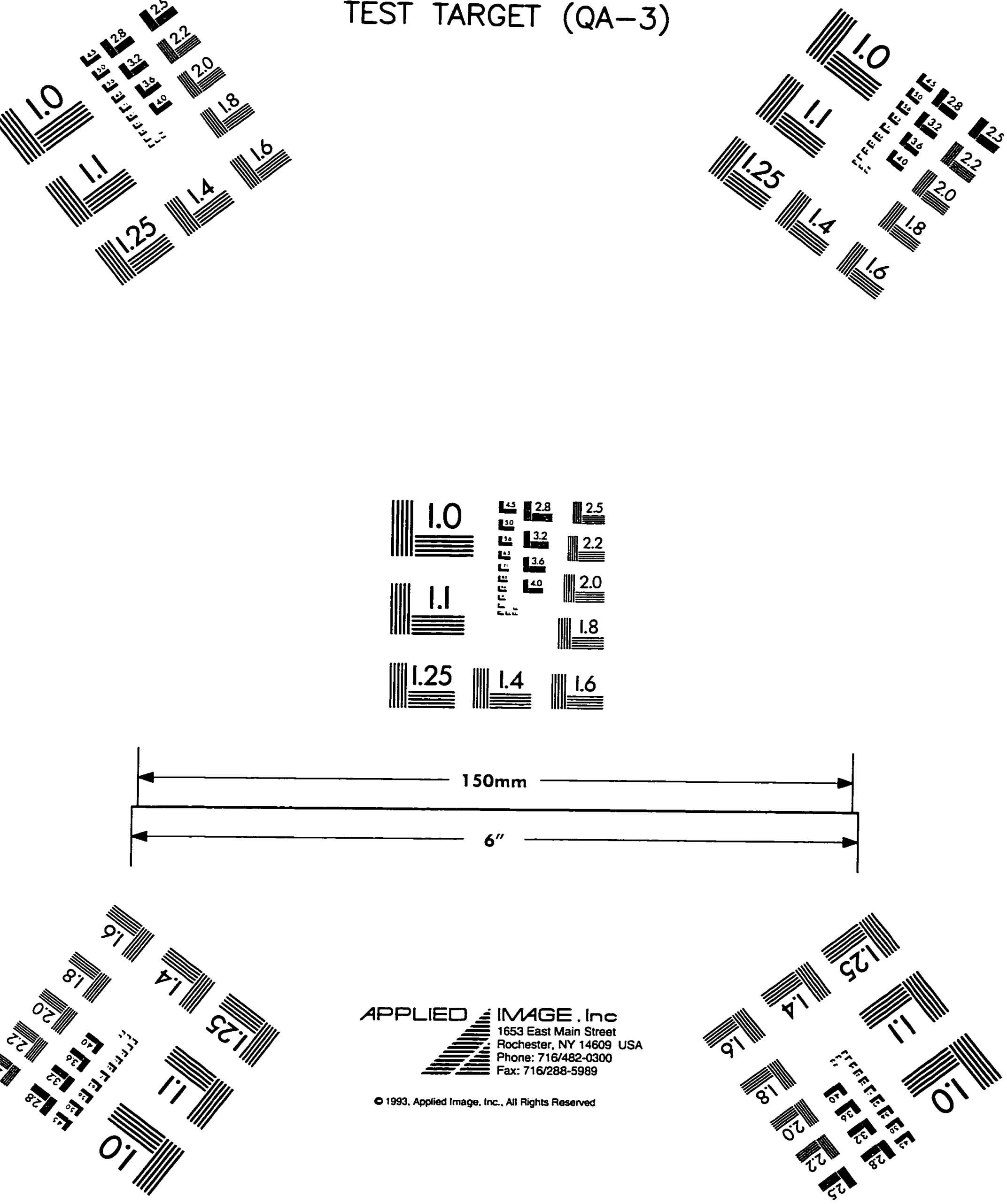